Available online:

http://journal.imla.or.id/index.php/arabi

Arabi : Journal of Arabic Studies, 3 (2), 2018, 121-144

DOI: http://dx.doi.org/10.24865/ajas.v3i2.96

\title{
PENGEMBANGAN MODEL PEMBELAJARAN BAHASA ARAB BERBASIS TEORI KONSTRUKTIVISME DI PERGURUAN TINGGI
}

\author{
Sahkholid Nasution, Zulheddi \\ Universitas Islam Negeri Sumatera Utara Medan, Indonesia \\ E-mail : sahkholidnasution@uinsu.ac.id
}

\begin{abstract}
This study aimed to: 1) describe the conditions of Arabic learning in the State Islamic university of North Sumatra (UIN SU) Medan; 2) develop the Arabic language learning model based on constructivism theory; and 3) know the level of validation of the Arabic language learning model based on constructivism theory. This research applied Research and Development $(R \& D)$ method with Four Ds model consisting of: define, design, development and dissemination. The results showed (1) the Arabic learning at UIN SU Medan needed much improvement because $48.32 \%$ of Arabic language lecturers still used a learning approach not encouraging students to learn actively, collaboratively, and confidently. In other words, the learning process was still teacher-centered. (2) The product (Arabic Language Learning Model) produced was an Arabic learning tool characterized by constructivism, which includes: Syllabus, RPS and Assessment. (3) Constructivism learning and Arabic learning experts assessed the products with an average value of 3.37 (very good).
\end{abstract}

Keywords: Arabic Language, Constructivism, Development, Learning Model

\begin{abstract}
Abstrak
Penelitian ini bertujuan untuk: (1) mendeskripsikan realitas pembelajaran bahasa Arab di UIN SU Medan, (2). Mengembangkan model pembelajaran bahasa Arab berbasis teori konstruktivisme, dan (3). Mengetahui tingkat validasi model pembelajaran bahasa Arab berbasis teori konstruktivisme di UIN Sumatera Utara Medan. Penelitian ini termasuk penelitian dan pengembangan $(\mathrm{R} \& \mathrm{D})$ dengan jenis model Four D's, terdiri dari empat langkah: define, desain, development dan dessimination. Hasil penelitian ini adalah (1) Pembelajaran bahasa Arab di UIN Sumatera Utara Medan masih sangat perlu untuk diperbaiki dan ditingkatkan, sebab terdapat 48,32\% dosen bahasa Arab masih memakai pendekatan pembelajaran yang belum mendorong mahasiswa untuk belajar aktif, kolaboratif, dan percaya diri. Proses pembelajaran yang digunakan masih bersifat teacher-center. (2) Produk (Model Pembelajaran Bahasa Arab) yang dihasilkan adalah perangkat pembelajaran bahasa Arab berciri khas konstruktivisme, yang mencakup: Silabus, RPS dan Penilaian. (3) Para ahli pembelajaran konstruktivisme dan pembelajaran bahasa Arab menilai produk penelitian dengan nilai rata-rata 3.37 (sangat baik).
\end{abstract}

Kata Kunci: Bahasa Arab, Konstruktivisme, Pengembangan, Model Pembelajaran 


\section{Arabi : Journal of Arabic Studies}

\section{Pendahuluan}

Secara umum pembelajaran Bahasa Arab di Indonesia di semua jenis dan jenjang pendidikan belum berhasil seperti yang diharapkan. Indikator hal tersebut dapat dilihat dari minat dan kemampuan sebagian besar siswa dan/atau mahasiswa yang rendah, jika dibanding dengan minat dan kemampuan mereka dalam menguasai bahasa asing lainnya, khususnya bahasa Inggris.

Pembelajaran bahasa Arab di Perguruan Tinggi Islam di Indonesia, baik negeri maupun swasta, adalah wajib. Secara akademis, kebijakan ini memberi peluang yang sangat besar bagi pengembangan bahasa Arab di Tanah Air. Jumlah Perguruan Tinggi Islam di tanah air saat ini tidak kurang dari 52 Perguruan Tinggi, ditambah lagi beberapa Perguruan Tinggi Umum yang mempelajari bahasa Arab, khususnya di prodi-prodi kajian Timur Tengah dan Sastra Arab.

Namun demikian, besarnya peluang pengembangan bahasa Arab ini, tidak berbanding lurus dengan keberhasilan pembelajaran bahasa Arab itu sendiri. Tidak sedikit mahasiswa Perguruan Tinggi Keagamaan Islam Negeri (PTKIN) maupun Perguruan Tinggi Keagamaan Islam Swasta (PTKIS) yang telah menyelesaikan studinya tetapi belum bisa berkomunikasi secara baik dan benar dalam bahasa Arab dan juga belum bisa merujuk kitab-kitab turäts secara maksimal dalam memperkuat ide dan gagasannya. Kondisi ini menunjukkan bahwa banyak di antara lulusan PTKIN dan PTKIS yang nota bene ilmuan atau calon ilmuan muslim yang belum menguasai bahasa Arab dengan baik. Padahal, salah satu pembeda lulusan PTKI dengan Perguruan Tinggi Umum (PTU) adalah kemampuannya dalam berbahasa Arab.

Menurut Hizbullah dan Mardiah (2014), diakui bahwa banyak faktor yang melatarbelakangi problema tersebut; kualifikasi dan/atau kompetensi tenaga pendidik yang belum maksimal, ketersediaan sarana dan prasarana yang kurang/tidak memadai, kebijakan pemerintah yang belum mendukung, lingkungan bahasa yang belum terkondisikan, minat belajar siswa/mahasiswa yang rendah, anggapan bahwa bahasa Arab tidak penting cukup tinggi, dan lain-lain.

Dari semua faktor tersebut, poin yang digali dalam penelitian ini adalah kompetensi tenaga pendidik yang belum maksimal. Hal ini terbukti bahwa banyak guru/dosen bahasa Arab yang keliru dalam memilih dan menggunakan teori/pendekatan, strategi dan teknik dalam mengajar bahasa Arab. Misalnya, pembalajaran mahārah istimā' guru/dosen menggunakan metode al-qawā'id wa altarjamah, maka dapat dipastikan bahwa kompetensi yang diinginkan tidak akan tercapai dengan baik. Diakui bahwa tidak ada pendekatan, strategi, metode dan teknik pembelajaran yang bisa diklaim lebih baik dan yang lain, karena masing-masing memiliki kelebihan dan kekurangan, tetapi yang bisa dipastikan hanyalah bahwa pendekatan, strategi, metode dan teknik pembelajaran dalam konteks tertentu lebih sesuai dari yang lain (Fachrurrazi dan Mahyudin, 2016).

Dalam konteks pembelajaran di Perguruan Tinggi, secara psikis, mahasiswa telah sampai kepada kematangan berfikir secara mandiri, mereka telah memiliki pengalaman belajar yang cukup banyak, mulai dari SD, SLTP dan SLTA. Oleh karena itu, perlu diterapkan pendekatan pembelajaran yang relevan dengan kondisi tersebut, termasuk dalam pembelajaran bahasa Arab. Hal ini sesuai dengan Bruning (2004) sebagaimana dikutip oleh Schunk (2012:320) bahwa pendekatan konstruktivisme adalah prespektif psikologis dan filosofis yang memandang bahwa masing-masing individu membentuk dan membangun sebagian besar dari apa yang mereka pelajari dan pahami. Berdasarkan temuan penelitian Syafi'i (2008) bahwa model pembelajaran bahasa Arab berbasis Konstruktivisme dapat meningkatkan kinerja dosen, penggunaan waktu yang efektif dan proses pembelajaran terkonsentrasi. Perbedaan penelitian Syafi'i dengan penelitian ini adalah terletak pada produk yang dihasilkan; di mana produk penelitian yang dihasilkan Syafi'i melalui penelitiannya tidak dikonkretkan dalam perangkat pembelajaran, seperti produk penelitian ini.

Realitas menunjukkan bahwa sejumlah persoalan pembelajaran bahasa Arab di Perguruan Tinggi di Indonesia adalah: (1) Latar belakang mahasiswa yang sangat beragam, (2) Latar belakang dosen bahasa Arab tidak semuanya dari alumni pendidikan bahasa Arab, (3) Kompetensi dosen bahasa Arab tidak terstandar, (4) Kurikulum mata kuliah bahasa Arab tidak sentral, (5) 
Media pembelajaran bahasa Arab kurang mendukung, dan (6) Standar penilaian kompetensi berbahasa Arab belum ada.

Potensi pembelajaran bahasa Arab di UIN Sumatera Utara Medan cukup besar, paling itdak dapat dilihat dari dua aspek: (1) Input/mahasiswa yang masuk ke UIN Sumatera Utara Medan banyak berasal dari madrasah dan pesantren yang sangat banyak dan bertebaran di seluruh pelosok provinsi Sumatera Utara Medan, (2) Saat ini jumlah prodi (S.1) di delapan fakultas di UIN Sumatera Utara Medan telah mencapai 40 prodi. Semua prodi wajib membelajarkan bahasa Arab, sebab bahasa Arab telah menjadi mata kuliah universitas.

Namun demikian, selama ini pembelajaran bahasa Arab di UIN Sumatera Utara belum terorganisir dengan baik, masing-masing dosen mengajar bahasa Arab sesuai dengan kapasitas dan kapabilitasnya. Buku panduan yang tidak seragam, dan satu hal yang bisa dipastikan, bahwa penggunaan pendekatan behaviorisme dalam pembelajaran bahasa Arab sangat menonjol. Hal ini terbukti praktik menghafal yang tidak kreatif masih dialami para mahasiswa (Albantani, 2018). Untuk itulah, pengembangan model pembelajaran bahasa Arab berbasis pendekatan konstruktivisme sangat dibutuhkan.

Hasil penelitian tentang pengembangan pembelajaran berabasis konstruktivisme telah banyak dilakukan para ahli, antara lain: (1). Mar'atus Sholihah, dkk. Pengembangan Bahan Ajar Berbasis Konstruktivisme Dengan Mengoptimalkan Kecerdasan Majemuk Untuk Meningkatkan Kemampuan Berpikir Kritis Danprestasi Belajar Siswa Smp Bab Bunyi (FMIPA Universitas Negeri Malang, 2014), (2). Johar Maknun, Penerapan Pembelajaran Konstruktivisme Untuk Meningkatkan Pemahaman Konsep Dasar Fisika Siswa Sekolah Menengah Kejuruan (SMK), (FPTK Universitas Pendidikan Indonesia, 2007), (3). Endang Mulyatiningsih dan Sri Emy Yuli Suprihatin, Efektifitas Pembelajaran Konstruktivisme Dalam Pencapaian Kompetensi Dasar Mulok PPK Pada Siswa SLTP, (Fakultas Teknik UNY, 2005). (4). Michael Sri Rudianto, Pengembangan Model Pembelajaran Matematika Volum Benda PutarBerbasis Teknologi Dengan Strategi Konstruktivisme Student Active Learning Berbantuan CD Interaktif Kelas XII (Universitas Neger Semarang, 2006), (5). Lantip Dian Prasojo, Konstruktivisme Dalam Pendidikan Tinggi, (UNY, 2006), dan sebagainya.

Penelitian tentang konstruktivisme banyak berkaitan dengan ilmu-ilmu eksakta, sementara penelitian ini merupakan ilmu sosial, khususnya di bidang bahasa. Produk penelitian ini juga berbeda dengan penelitian-penelitian sebelumnya, yaitu model pembelajaran yang dikonkretkan dalam perangkat pembelajaran.

\section{Model Pembelajaran Bahasa Arab}

Dalam Kamus Besar Bahasa Indonesia (1995:662), model adalah "pola dari sesuatu yang akan dimuat atau dihasilkan." Menurut Pribadi (2011:86), model adalah "Sesuatu yang menggambarkan adanya pola berpikir. Sebuah model biasanya menggambarkan keseluruhan konsep yang saling berkaitan, dan juga dapat dipandang sebagai upaya untuk mengkongkretkan sebuah teori sekaligus juga merupakan sebuah analogi dan representasi dari varibel - varibel yang terdapat di dalam teori tersebut."Dapat dipahami bahwa di dalam sebuah model terdapat beberapa komponen yang saling terkait dan tidak terpisahkan antara satu sama lain.

Dalam konteks model pembelajaran, Sani (2013:89) menjelaskan bahwa "model pembelajaran merupakan kerangka konseptual berupa pola prosedur sistematik yang dikembangkan berdasarkan teori dan digunakan dalam mengorganisasikan proses belajar mengajar untuk mencapai tujuan belajar." Oleh Trianto (2013:22), "model bisa menjadi sarana untuk menerjemahkan teori ke dalam dunia kongkret untuk aplikasi ke dalam praktek." Menurut Joice 1992 -sebagaimana dikutip Trianto (2011:5) "model pembelajaran adalah "Rancangan atau suatu pola yang digunakan sebagai pedoman dalam merencanakan pembelajaran di kelas atau pembelajaran dalam tutorial dan untuk menentukan perangkat-perangkat pembelajaran, termasuk di dalamnya buku-buku, film, komputer, kurikulum, dan sebagainya." Dengan demikian, model 


\section{Arabi : Journal of Arabic Studies}

pembelajaran sangat terkait dengan pemilihan strategi metode, teknik dan taktik pembelajaran yang tergambar dalam tahapan atau sintaks pembelajaran. Menurut Nasution (2016:46), ada sejumlah model pembelajaran: Pertama, model behavioral/tingkah laku, yaitu model yang berbasis pada teori Behaviorsme. Kedua, Model Pemrosesan informasi dan Model Personal yang berbasis pada teori kognitivisme, serta model Konstruktif yang berbasis kepada teori konstruktifvisme. Maka dapat dipahami bahwa model pembelajaran memiliki makna yang lebih luas dari pendekatan, strategi, metode, atau prosedur. Dengan kata lain, di dalam model pembelajaran terdapat pendekatan, strategi, metode, teknik dan taktik pembelajaran, sebagaimana digambarkan oleh Nasution (2016:37) berikut:

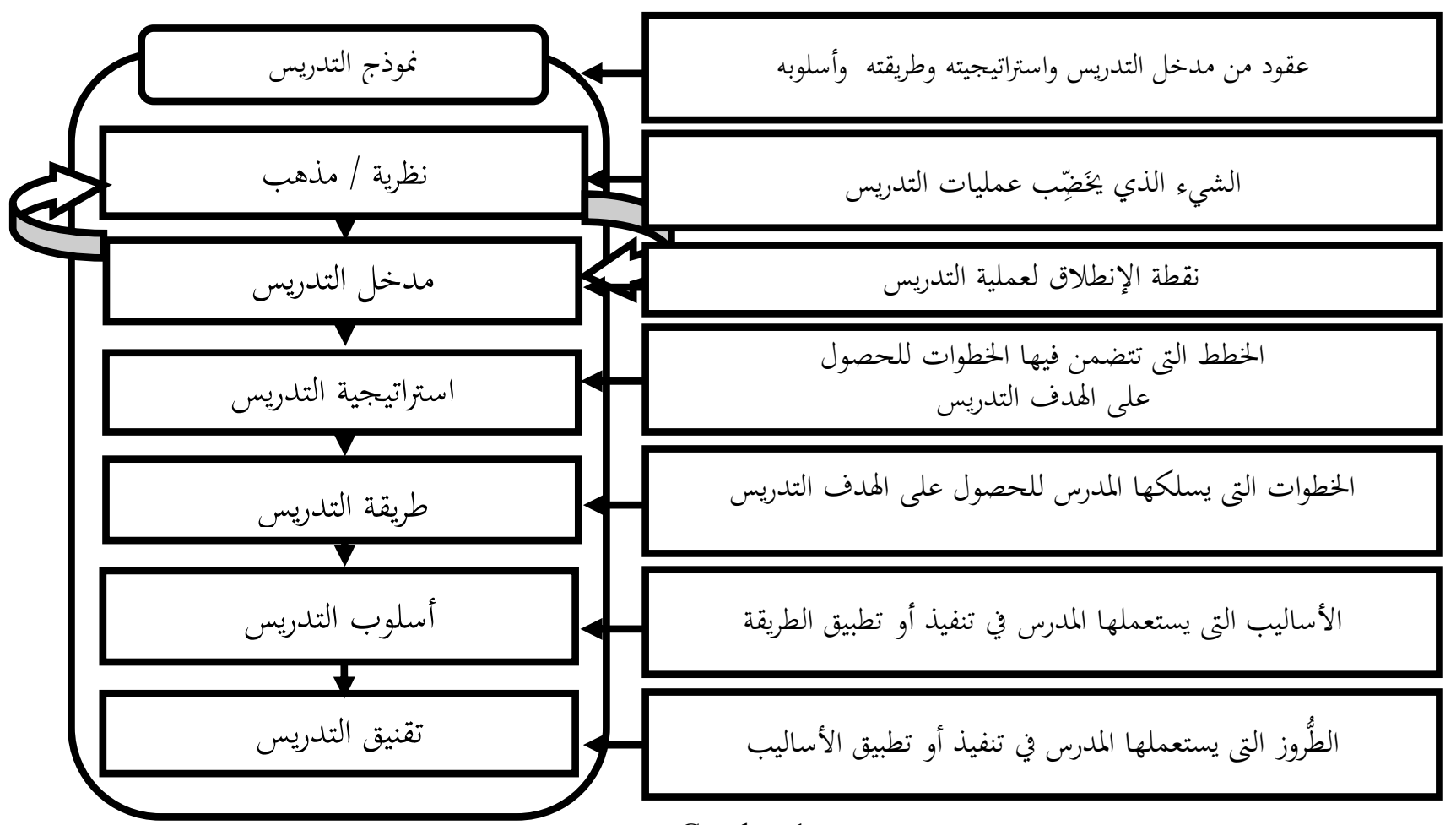

Gambar 1:

Hubungan antara Model dengan Pendekatan, Strategi, Metode, Teknik dan Taktik

Menurut Rusman (2012:133-134) “Ada beberapa hal yang harus dipertimbangkan guru dalam memilih sebuah model: (1). Pertimbangan tujuan yang hendak dicapai... (2) Pertimbangan bahan dan materi pembelajaran... (3). Pertimbangan perserta didik... (4). Pertimbangan lainnya yang bersifat nonteknis..."

Oleh karena itu, model pembelajaran mengarah pada suatu pendekatan tertentu, yang dalam hal ini adalah pendekatan konstruktivisme di UIN Sumatera Utara Medan, dengan pertimbangan sebagai berikut: (1) Berdasarkan tujuan pembelajaran, penggunaan pendekatan konstruktivisme dalam pembelajaran bahasa Arab dianggap relevan, sebab tujuan pembelajaran bahasa Arab di Perguruan Tinggi tidak sekadar terpokus pada keterampilan berbicara tetapi penguasaan secara seimbang terhadap semua keterampilan berbahasa Arab. Penggunaan pendekatan konstruktivisme mendukung untuk mencapai tujuan tersebut. (2) Dari segi bahan materi pembelajaran, penggunaan pendekatan konstruktivisme dalam pembelajaran bahasa Arab dianggap relevan, sebab bahan / sumber belajar diperguruan tinggi tidak hanya sekedar fakta, tetapi juga ada konsep hukum dan teori (Thu'aimah, 2010). Di samping itu, sumber belajar diperguruan tinggi sangat beragam dan memang harus beragam. (3) Pertimbangan dari sudut perserta didik, penggunaan pendekatan konstruktivisme dalam pembelajaran bahasa Arab dianggap relevan, sebab model pembelajaran yang berbasis konstruktivisme memerlukan kematangan berpikir, pengalaman dan minat/bakat peserta didik. Hal ini tentu ditemukan pada mahasiswa di Perguruan Tinggi, sesuai dengan usia mereka yang telah memasuki tahap dewasa. (4) Dari segi pertimbangan lainnya yang bersifat 
nonteknis, penggunaan pendekatan konstruktivisme dalam pembelajaran bahasa Arab dianggap relevan, sebab pembelajaran di perguruan tinggi tidak cukup hanya dengan satu metode, tetapi harus menggunakan banyak metode. Penggunaan metode yang cukup beragam adalah salah satu ciri dari pendekatan konstruktivisme (al-Shadiq, 2008).

Sebagaimana dijelaskan sebelumya bahwa model pembelajaran di dalamnya terdapat pendekatan, strategi, metode dan teknik pembelajaran. Menurut Rusman (2012:380) pendekatan merupakan "Titik tolak atau sudut pandang terhadap proses pembelajaran" Sani (2013:91) menegaskan, bahwa pendekatan pembelajaran adalah "Sudut pandang guru terhadap proses pembelajaran secara umum berdasarkan teori tertentu yang mendasari pemilihan strategi dan metode pembelajaran. Pendekatan/teori pembelajaran adalah titik tolak seorang guru dalam memandang pembelajaran. Menurut Anthony (1963) sebagaimana dikutip oleh Pranowo (2014:259), pendekatan dalam kaitannya dengan bahasa, adalah "Asumsi teoritis yang barikaitan dengan hakikat bahasa, belajar bahasa dan pengajaran bahasa."

Secara umum, paling tidak ada dua pendekatan dalam pembelajaran, termasuk dalam pembelajaran bahasa Arab, yaitu: Pertama, pendekatan pembelajaran yang berpusat pada guru. Kedua, pendekatan pembelajaran yang berpusat pada siswa. Pendekatan pembelajaran yang berpusat pada guru melahirkan beberapa strategi pembelajaran, diantaranya adalah strategi langsung. Sementera pendekatan pembelajaran yang berpusat pada siswa juga melahirkan sejumlah strategi pembelajaran, diantaranya strategi pembelajaran tidak langsung dan strategi discovery.

Menurut Madkur (2010:81) diantara pendekatan/teori belajar mengajar bahasa adalah: Teori Struktural, Teori Behaviorisme dan Teori Kognitivisme. Menurut al-Ushaily (2002:21- 22), salah satu pendekatan yang paling populer dalam pembelajaran bahasa asing, termasuk pembelajaran bahasa Arab, adalah pendekatan konstruktivisme. Lebih lanjut al-Ushaily menyatakan "Diantara pendekatan yang populer dalam pembelajaran bahasa asing adalah pendekatan dengar-ucap, pendekatan natural, pendekatan kognitif, pendekatan komunikatif, pendekatan fungsional, pendekatan konstruktif, pendekatan kondisional, pendekatan humanis, pendekatan analisis dan non analisis

Menurut Bruning (2004) sebagaimana dikutip oleh Schunk (2012:320) bahwa pendekatan konstruktivisme adalah prespektif fisikologis dan filosofis yang memandang bahwa masing masing individu membentuk dan membangun sebagian besar dari apa yang mereka pelajari dan pahami. Educational Broadcasting Corporation -sebagaimana dikutip Nurohman (2008:134)memberikan batasan tentang pendekatan konstruktivisme "Constructivism is basically a theory based on observation and scientific study about how people learn. Its says that people construct their own understanding and knowledge of the word, throgh experiencing things and reflecting on those experiences.

Menurut Pranowo (2014:47-48) "Pendekatan konstruktivisme dalam pembelajaran bahasa dipandang sebagai pendekatan mutakhir. Pendekatan ini dipandang sebagai pendekatan yang paling sesuai dengan sifat-sifat dasar belajar anak. Anak memiliki kebebasan untuk mengonstruk pengetahuan berdasarkan perkembangan pikirannya. Namun, kebebasan yang dimiliki anak tidak dibiarkan liar tanpa pendampingan oleh guru. Guru sebagai fasilitator yang memberikan kemungkinan untuk ikut campur tangan dalam proses belajar anak. Kebebasan yang dimaskud dalam konstruktivisme adalah kebebasan yang teramati sesuai dengan perkembangan kognitif anak. Anak merangkai pengetahuan atas dasar pengetahuan yang sudah dimiliki. Oleh karena itu, peranan motivasi, konteks sosial, karakteristik individu sangat menentukan tingkat pemahamannya." Dengan demikian, konstruktivisme dalam konteks pembelajaran secara umum dan pembelajaran bahasa Arab secara khusus, merupakan sebuah landasan psikologis dan filosofis yang memandang bahwa peserta didik dapat membentuk dan mengembangkan pemahamannya secara mandiri berdasarkan pengalaman dan pengetahuan sebelumnya sesuai dengan rangsangan yang diberikan oleh guru (al-Fauzan, 2011). 


\section{Arabi : Journal of Arabic Studies}

Duffy dan Cunningham, dalam Jonassen (2003) sebagaimana dikutip Pribadi (2011: 155-156) menjelaskan bahwa beberapa alasan rasional yang melatarbelakangi penggunaan pendekatan konstruktivisme dalam proses pembelajaran yaitu: (1) Semua pengetahuan dan hasil belajar merupakan proses konstruksi pribadi. (2) Pengetahuan merupakan konstruksi peristiwa yang dialami dari berbagai sudut pandang atau perspektif. (3) Proses belajar harus berlangsung dalam konteks yang relevan. (4) Belajar dapat terjadi melalui media pembelajaran (5) Belajar merupakan dialog sosial yang bersifat inhern. (6) Siswa yang belajar memiliki ragam latar belakang yang multidimensial, dan (7) Memahami pengetahuan yang dipelajari merupakan pencapaian utama manusia.

Jika pendapat di atas dihubungkan dengan pembelajaran bahasa, termasuk bahasa Arab, maka pendekatan konstruktivisme relavan diaplikasikan dalam pembelajaran bahasa Arab untuk non Arab, terutama di Perguruan Tinggi. Sebab keberhasilan pembelajaran bahasa, seperti bahasa Arab, membutuhkan proses pembelajaran yang mengedepankan pada optimalisasi kemampuan peserta didik dengan segala keragaman latar belakangnya melalui pembelajaran yang bersifat kontekstual dan mandiri. Latar belakang peserta didik di Perguruan Tinggi juga sangat beragam disamping tingginya tuntutan kemandian mahasiswa dalam belajar di Perguruan Tinggi.

Driver dan Oldman dalam Matthews, sebagaimana dikutip Suparno (2007:69-70), menjelaskan bahwa beberapa ciri pembelajaran konstruktivis adalah: (1) Orientasi, murid diberi kesempatan untuk mengembangkan motivasi dalam mempelajari suatu topik, (2) Elicitasi, murid dibantu untuk mengungkapkan idenya secara jelas dengan berdiskusi, menulis, membuat poster dan lain-lain, (3) Restrukturisasi ide, bisa dalam bentuk klarifikasi ide, membangun ide baru, dan mengevaluasi ide, (4) Penggunaan ide dalam banyak situasi, agar pengetahuan siswa lebih lengkap dan bahkan lebih rinci dengan segala macam pengecualiannya, (5) Review, bagaimana ide itu berubah ke arah yang lebih baik.

Seiring dengan itu Pranowo (2014:44-45) menjelaskan, bahwa di antara implikasi pendekatan konstruktivisme dalam pembelajaran bahasa adalah sebagai berkut: (1) Guru bahasa harus menguasai bahasa yang diajarkannya secara baik dan memiliki pengetahuan dan pengalaman bagaimana mengajarkan bahasa tersebut, serta memiliki prinsip-prinsip umum linguistik. (2) Latihan pengucapan harus diberikan sejak awal dengan maksud untuk membentuk kebiasaan yang otomatis dalam mengucapkan bunyi-bunyi bahasa yang dipelajari secara benar tanpa ragu-ragu, (3) Cara melatih ucapan diawali dengan pemberikan deskripsi sederhana sebagaimana suatu bunyi bahasa dihasilkan dan diperbandingkan dengan bahasa pertama pembelajar. (4) Metode penyajian semantik dalam arti penyajian digunakan metode langsung, maksudnya pemakaian bahasa ibu dihindarkan, diberikan dengan teks secara berulang-ulang dalam membaca, mendengarkan dan menulis. (5) Informasi gramatikal diberikan untuk mempermudah proses mempelajari bahasa. informasi mengenai tata bahasa bukan merupakan tujuan pengajaran. Oleh karena itu, pengajaran harus disampaikan secara induktif, (6) Teks bacaan yang diberikan harus berisi kehidupan dan kebudayaan penutur asli bahasa yang dipelajari dengan memperhatikan tingkat kesukaran bahasa dan isinya, (7) Interpretasi terhadap isi teks hendaknya dilakukan interpretasi secara pedagogik.

Dengan demikian, pendekatan konstruktivisme dalam pembelajaran bahasa Arab, membutuhkan guru yang mampu merancang dan menciptakan pengalaman-pengalaman belajar pada anak didik, agar mereka mampu mengaitkan dan memaknai konsep-konsep bahasa Arab yang mereka pelajari. Belajar bahasa Arab tidak sekadar peniruan melalui lingkungan bahasa, tetapi peserta didik didorong untuk mampu membangun pengetahuan bahasa Arabnya secara mandiri melalui proses pembelajaran di dalam dan di luar kelas serta evaluasi autentik, seperti portofolio (Asrori, et.al, 2014).

Tidak dapat dimungkiri bahwa para ahli berbeda pendapat dalam memberikan definisi, batasan dan urutan antara istilah model, pendekatan, strategi, metode, teknik dan taktik pembelajaran. Namun demikian, berdasarkan penjelasan sebelumnya dapat dipahami bahwa di dalam model ada pendekatan, strategi, metode, teknik dan taktik pembelajaran. Dengan demikian,

Vol. 3 No. 2 | 126-144

Copyright ( 2018 | ARABI | p-ISSN 2548-6616 | e-ISSN 2548-6624 
pembelajaran yang berbasis pada pendekatan konstruktivisme memiliki strategi dan metode khusus yang relevan dengan pendakatan ini.

Menurut Dick dan Carey (2015), sebagaimana dikutip Yamin (2013:5), "Strategi pembelajaran menjelaskan komponen-komponen umum dari seperangkat bahan pembelajaran dan porsedur-prosedur yang akan digunakan bersama bahan-bahan tersebut. Komponen-komponen dimaksud adalah: Pertama, Pra-instruksional, mencakup: motivasi, tujuan dan tingkah laku awal. Kedua, penyajian informasi, berisi: urutan pembelajaran, informasi dan contoh-contoh. Ketiga, peran serta pembelajar, berisi: latihan dan umpan balik. Keempat, tes, berisi: tes awal dan tes akhir dan Kelima, kegiatan tidak lanjut, berisi: perbaikan, pengayaan, transfer dan pendalaman." Strategi didefenisikan sebagai "Rencana tindakan termasuk penggunaan metode dan pemanfaatan berbagai sumber daya dalam pembelajaran" (Yamin (2013:89). Dengan kata lain, strategi adalah sebuah konsep yang bersifat rancangan, dipilih untuk mencapai tujuan pembelajaran yang telah ditentukan. Dengan demikian, dapat dipahami bahwa strategi pembelajaran lebih umum dari pada metode. Strategi pembelajaran bersifat abstrak dan lebih kepada perencanaan menyeluruh dalam memilih metode, teknik dan taktik pembelajaran.

Sanjaya (2007:128-129) membagi strategi pembelajaran kepada tiga: Pertama, Strategi Pembelajaran langusng, Kedua, Strategi Pembelajaran Kelompok dan Ketiga, Strategi Pembelajaran Mandiri. Menurut Wardoyo (2013:44), di antara strategi pembelajaran yang tergabung dalam pendekatan konstruktivisme adalah Cooveratif Learning, Contextual Teaching and Laearning, Inkuiri Learning dan Problem Based Learning.

\section{a. Strategi Pembelajaran Kooperatif (Cooveratif Learning)}

Menurut Sani (2013:131), pembelajaran kooperatif dilakukan dengan cara meningkatkan aktivitas belajar bersama sejumlah peserta didik di dalam satu kelompok. Aktivitas pembelajaran kooperatif menekankan pada kesadaran peserta didik untuk saling membantu mencari dan mengolah informasi, mengaplikasikan pengetahuan dan keterampilan. Tujuan pembelajaran kooperatif adalah: (1) Melatihkan keterampilan sosial, seperti tenggang rasa, bersikap sopan terhadap teman, mengkritik ide orang lain, (2) Berani mempertahankan pikiran yang logis, (3) Melatih peserta didik dalam setiap kelompok supaya bertanggung jawab dalam belajar, (4) Meningkatkan rasa saling percaya diri kepada seama, (5) Meningkatkan kemampuan memandang masalah dan situasi dari berbagai perspektif, dan (6) Meningkatkan kemampuan menjalin hubungan interpersonal.

\section{b. Strategi Pembelajaran Contextual Teaching and Laearning}

Rusman (2012:190) menjelaskan bahwa pembelajaran konstektual yang memberikan fasilitas kegiatan belajar peserta didik untuk mencari, mengolah, dan menemukan pengalaman belajar yang lebih bersifat konkret (terkait dengan kehidupan nyata) melalui keterlibatan aktivitas siswa dalam mencoba, melakukan, dan mengalami sendiri. Dengan demikian, pembelajaran tidak sekadar dilihat dari sisi peroduk, akan tetapi yang terpenting adalah proses.

Depdiknas, (2002:20) dalam Rusman (2012:198) menjelaskan ciri-ciri pembelajaran kontektual: (1) Kerja sama, (2) Saling menunjang, (3) Menyenangkan dan tidak membosankan, (4) Menggunakan berbagai sumber, (5) Pembelajaran terintegrasi, (6) Belajar dengan bargairah, (7) Siswa Aktif, (8) Sharing dengan teman, (9) Siswa kritis guru kreatif, (10) Dinding kelas dan lorong-lorong penuh dengan hasil karya siswa, (11) Laporan kepada orang tua tidak hanya rapor, tetapi hasil karya siswa, laporan hasil praktikum, karangan siswa dan lain-lain.

\section{c. Startegi Pembelajaran Berbasis Masalah (Problem Based Learning)}

Secara historis, sebanarnya pembelajaran berbasis masalah (Problem Based Learning) telah muncul sejak zaman John Dewey. Dewasa ini mulai kembali muncul kepermukaan, mengingat strategi pembelajaran ini dapat memberikan kemudahan kepada peserta didik untuk melakukan penyelidikan dan ingkuiri atas masalah nyata yang mereka temukan. 


\section{d. Strartegi Pembelajaran Tidak Lansung (Indirect Instruction)}

Disebut strategi tidak langsung, karena guru berperan sebagai fasilitator dalam proses pembelajaran. Penyampaikan materi seakan tidak langsung diberikan kepada siswa, tetapi melalui berbagai cara, media dan sumber belajar sehingga akhirnya materi dapat dipahami dengan baik oleh peserta didik.

Startegi Pembelajaran Tidak Langsung (Indirect Instruction) sangat tepat dipraktikkan jika dilakukan hal-hal berikut: (1) Hasil belajar yang diharapkan berupa kemampuan berpikir tingkat tinggi, (2) Sikap, nilai, dan kemampuan interpersonal diharapkan dimiliki oleh perserta didik, (3) Proses belajar dinilai sama penting dengan produk belajar, (4) Peserta didik perlu menyelidiki atau menemukan sesuatu untuk mempelajari materi selanjutnya, (5) Dibutuhkan beberapa jawaban untuk suatu permasalahan, (6) Fokus pada pemahaman personal dan dan memori jangka panjang, (7) Keterlibatan individu dan motivasi instrinsik diharapkan muncul, (8) Dibutuhkan pengambilan keputusan dalam menyelesaikan permasalahan, (9) Kemampuan belajar sepanjang hayat perlu dikembangkan (Sani, 2013:148).

Sementara itu, tidak dapat dimungkiri bahwa para ahli berbeda pendapat dalam merumuskan definisi strategi dan metode. Ada yang mengatakan strategi lebih luas dari metode, dan ada yang berpendapat bahwa strategi bagian dari metode. Sungguh sangat beragam redaksi definisi metode oleh banyak ahli. Tetapi yang jelas antara satu dengan yang lain saling melengkapi. Intinya adalah, metode sangat tergantung kepada strategi dan pendekatan yang digunakan. Metode terganting kepada strategi, dan strategi berganting kepada pendekatan.

Terdapat sejumlah metode pembelajaran, termasuk pembelajaran bahasa Arab. Menurut alQursy (2009:16), diantara beberapa metode pembelajaran bahasa Arab adalah: al-Thariqah alIlqaiyah, Thariqah al-Asilah, al-Tharīqah al-Hiwāriyah, Thariqah Hill al-Musykilah, al-Thariqah al-Qiyāsiah/Istintäjiyah, al-Thariqah al-Istiqräiyah/Istinbathiyah, al-Thariqah al-Jam'iyah, alThariqah al-Tahliliyah al-Tarkibiyah, Thariqah al Nahwi wa al-Tarjamah, Thariqah alMubāsyarah, Tharìqah al-Qirā'ah, al-Thariquah al-Sam'iyah al-Syafawiyah, al-Thariquah alSam'iyah al-Bashariyah, al-Tharīqah al-Tawāshuliyah, Tharīqah al-Istijābah al-Jismiyah alKāmilah, al-Thariqah al-Shāmitah, al-Tharíqah al-Ihäiyah, al-Thariqah al-Thabỉ'iyah.

\section{Desain Pembelajaran Bahasa Arab berbasis Pendekatan Konstruktivisme}

Menurut Gagnoon dan Collay (2001) sebagaimana dikutip Pribadi (2011:155-156), bahwa desain pembelajaran berbasis pendekatan Konstruktivisme adalah sebagai berikut: (1) Situasi, yaitu penjelasan tentang tujuan dan tugas-tugas selama dan sesudah proses pembelarajan. (2) Pengelompokan, yaitu pembentukan kelompok-kelompok diskusi agar peserta didik dapat melakukan interaksi dengan teman sejawatnya. Proses pembentukan kelompok diskusi bisa dilakukan secara acak atau berdasarkan kritera tertentu. (3) Pengaitan, yaitu menghubungkan pengetahuan yang telah dimiliki oleh anak didik dengan dengan materi yang akan dipelajari. Hal ini bisa dilakukan dengan pemecahan masalah atau mendiskusikan tema-tema spesifik. (4) Pertanyaan, yaitu memberikan/melontarkan pertanyaan kepada peserta didik, baik dari guru maupun antar siswa. Melalui pertanyaan akan muncul gagasan orisinal siswa yang merupakan inti dari pendekatan pembelajaran konstruktivisme, yang pada akhirnya siswa dapat membangun pengetahuannya secara mandiri. (5) Eksibisi, yaitu memberikan kesempatan kepada siswa untuk menunjukkan hasil belajarnya setiap setelah proses pembelajaran selesai. Melalui tahapan ini, akan diketahui dengan jelas, pengetahuan seperti apa yang telah dibangun oleh peserta didik di dalam dirinya. (6) Refleksi, yaitu memberikan kesempatan kepada peserta didik untuk berfikir kritis tentang pengalaman belajar yang telah diikuti dan bagaimana cara mengaplikasikannya dalam situasi riil (al-Shumaily, 1998).

Senada dengan itu, al-Dhawiy (2013: 52-53) menjelaskan bahwa: 
تتميز البنائية بأها تجمع بين كونها نظرية في المعرفة، ومنهجا في التفكير وطريقة في التدريس. وقد تعددت تطبيقات

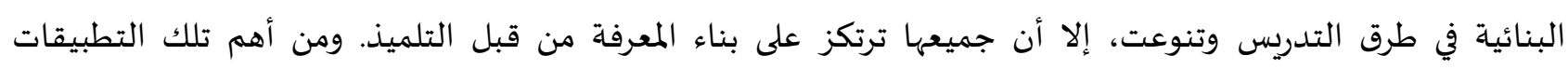

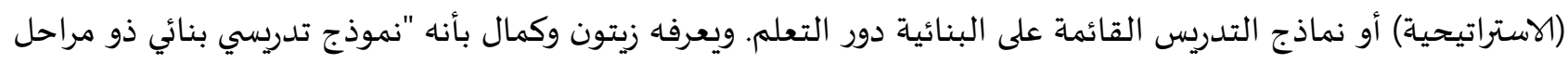

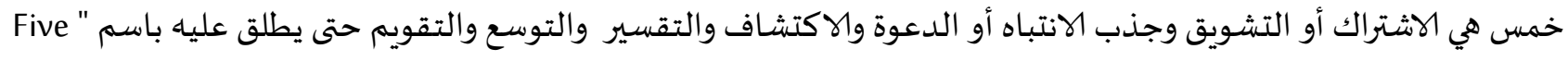

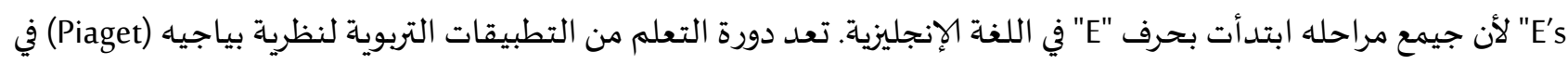
ميدان المناهج وطرق التدريس.

Berdasarkan pendapat di atas, dapat dipahami bahwa ada lima tahapan dalam pembelajaran berbasis konstruktivisme, sebagaimana dijelaskan dalam gambar berikut:

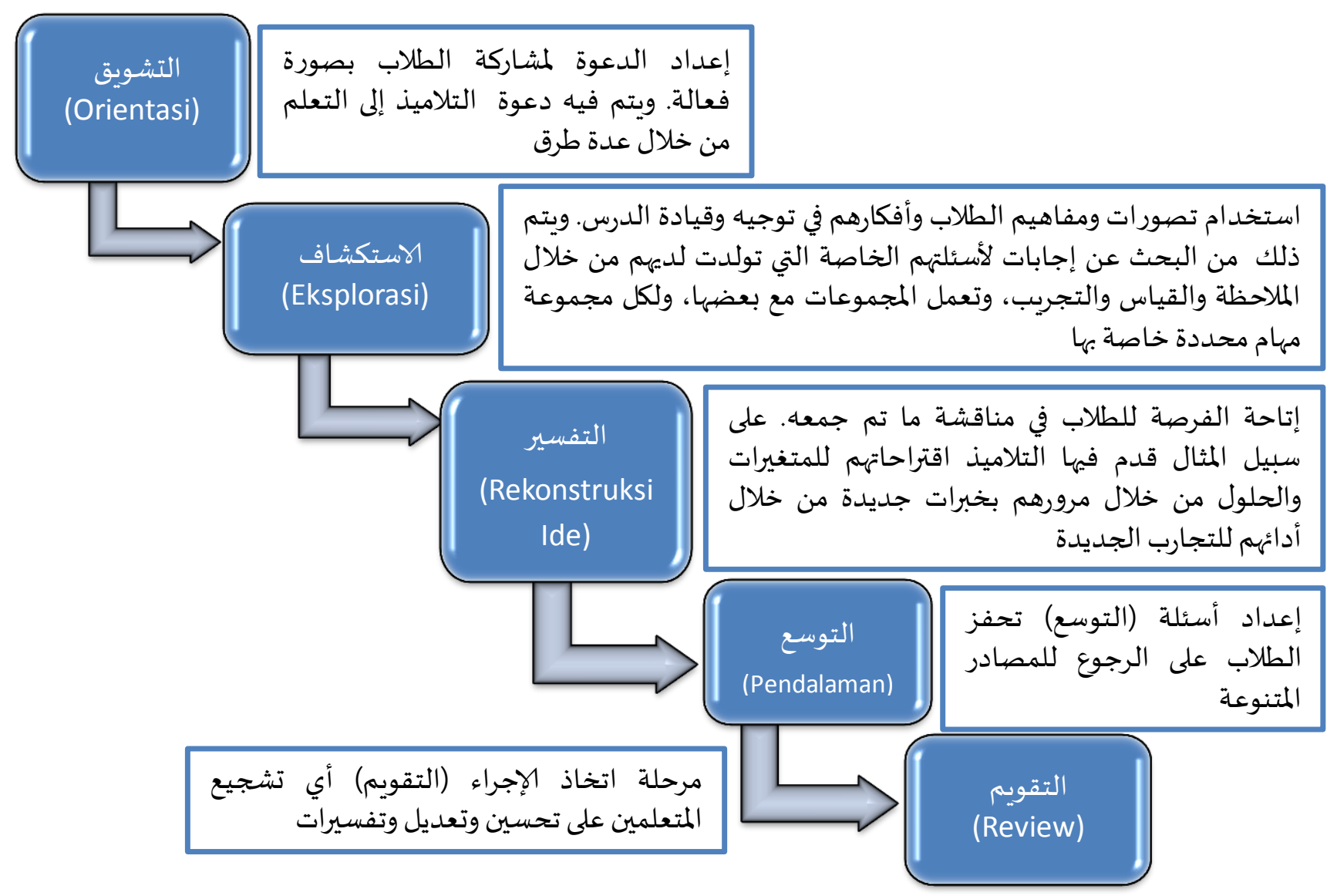

Gambar 2:

Tahapan Pembelajaran Berbasis Konstruktivisme

Kesemua langkah pembelajaran model konstruktivisme tersebut tergambar dalam perangkat pembelajaran bahasa Arab sebagai produk dari penelitian ini, yang mencakup: Silabus, Rencana Pembelajaran Semester (RPS), dan Evaluasi Pembelajaran.

\section{Metode Penelitian}

Penelitian ini adalah penelitian pengembangan (Research and Development). Jenis desain pengembangan yang digunakan adalah model Four-D's. Dengan alasan, karena produk dari pengembangan ini adalah model pembelajaran yang dikonkretkan dalam bentuk perangkat pembelajaran. Menurut Thiagarajan, Semmel dan Semmel (pencetus model Four D's 1974) menyarankan untuk memakai model ini, jika ingin menghasilkan produk perangkat pembelajaran. Model Four-D's memiliki empat langkah, sebagai berikut: 


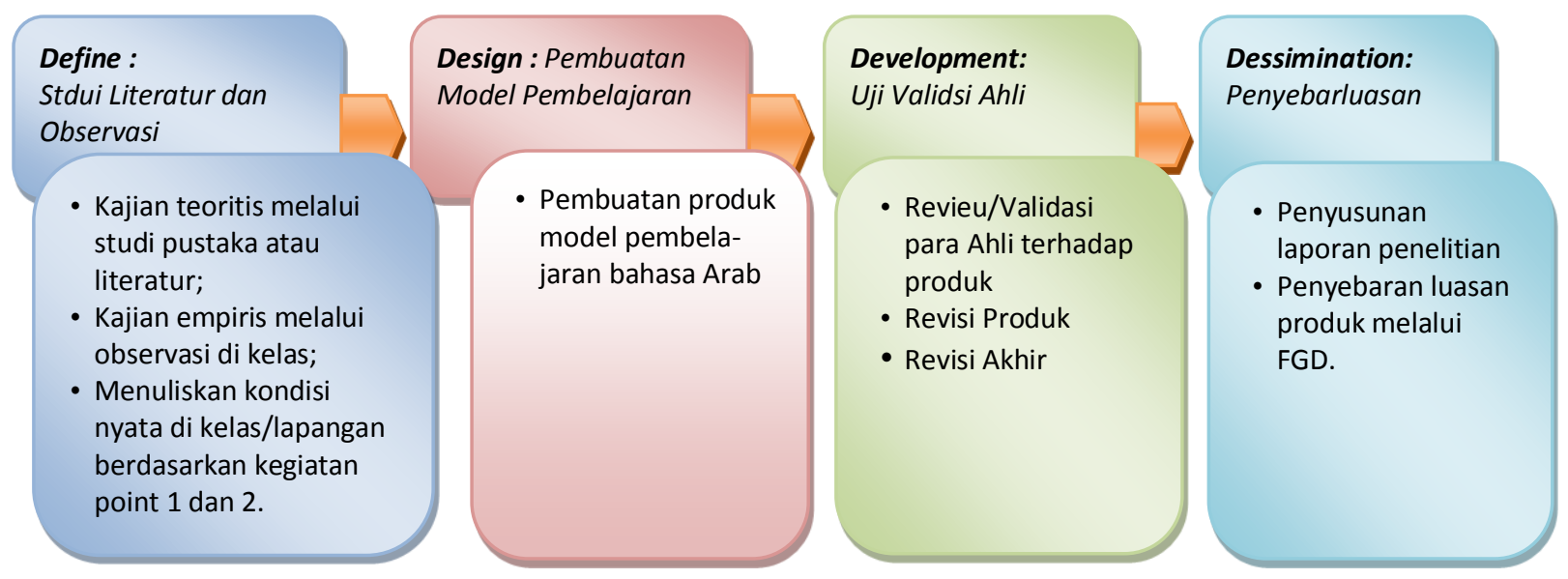

Gambar 3:

Langkah-Langkah Pengembangan

Sementara itu, teknik dan Instrumen Pengumpulan Data penelitian ini adalah (1) Observasi, metode ini dilakukan untuk melihat dan mengetahui secara jelas seperti apa proses pembelajaran bahasa Arab yang dilakukan oleh dosen-dosen bahasa Arab di Universitas Islam Negeri Sumatera Utara. Alat pengumpul data yang dipakai adalah penduan observasi dengan jenis jenis pilihan: ya dan tidak. (2) Wawancara, metode ini bertujuan untuk mengetahui secara jelas alasan para dosen bahasa Arab di Universitas Islam Negeri Sumatera Utara dalam memilih dan memakai pendekatan, strategi dan metode pembelajaran yang mereka terapkan di kelas. Adapun alat pengumpul data yang dipakai adalah panduan wawancara tertutup. Perekaman data dan fakta di lapangan bertujuan untuk mendapatkan gambaran yang lebih realistis tentang pembelajaran bahasa arab yang selama ini dilakukan atau tidak dilakukan oleh dosen bahasa Arab. (3) Angket, metode ini bertujuan untuk mengetahui kelayakan produk yang dikembangkan menyangkut pengembangan model pembelajaran bahasa Arab berbasis konstruktivisme oleh para ahli, yakni ahli di bidang pembelajaran bahasa Arab dan ahli di bidang teori konstruktivisme. Alat pengumpul data yang dipakai adalah lembar angket yang diberikan kepada para ahli saat mereka diminta membarikan verifikasi terhadap peroduk yang dikembangkan. (4) Studi pustaka, dengan mempelajari serta mengumpulkan data-data, berbagai reference (literature) dan sumber bacaan yang mendukung penelitian. Peneliti berpandangan bahwa literatur merupakan hal amat penting dalam suatu penelitian. Ketersediaan literatur dengan mempertimbangkan relevansi konsep-konsep yang digunakan dalam memperkuat teori dalam menjelaskan berbagai fenomena penelitian. (5) Wawancara dan Focus Group Discussion (FGD) dengan beberapa sumber yang ditetapkan untuk menjadi key-informan tentang pembelajaran bahasa Arab oleh dosen-dosen bahasa Arab di UIN Sumatera Utara Medan.

Untuk menvaliasi desain penelitian yang dikembangkan, dipilih beberapa orang verifikator yang dinggap kompeten di bidangnya untuk memberikan penilaian dan perbaikan terhadap pemgembangan model pembelajaran bahasa Arab berbasis konstruktivisme. Pada ahli dimaksud terdiri dari 2 orang ahli di bidang model pembelajaran konstruktivisme dan doa orang ahli di bidang pembelajaran bahasa Arab.

Karena penelitian ini adalah penelitian pengembangan, maka teknik analisa data yang dipakai ada bersifat kualitatif dan kuantitatif. Analisis data kualitatif dilakukan dalam bentuk mereduksi data teori untuk pengembangan model pembelajaran bahasa Arab, disamping mempertimbangkan berbagai masukan dari informan dan ahli.

Untuk data hasil observasi tentang kondisi pembelajaran bahasa Arab di UIN Sumatera Utara Medan dan hasil validasi para ahli terhadap produk model pembelajaran bahasa Arab yang 
dikembangkan dianalisis secara kuantitatif. Rumus yang digunakan adalah rumus persentase seperti berikut:

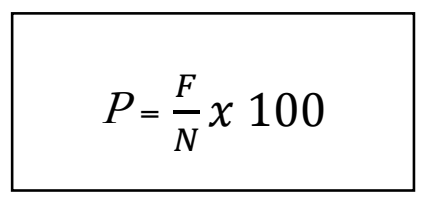

$$
\begin{aligned}
& \text { Keterangan: } \\
& \begin{array}{ll}
\mathrm{P} & =\text { Persentase } \\
\mathrm{F} & =\text { Frekunsi } \\
\mathrm{N} & =\text { Jumlah Jawaban }
\end{array}
\end{aligned}
$$

Karena validator/ahli terdiri dari empat orang, maka untuk menghitung nilai akhir terkait dengan tingkat validasi produk, digunakan rumus sebagai berikut:

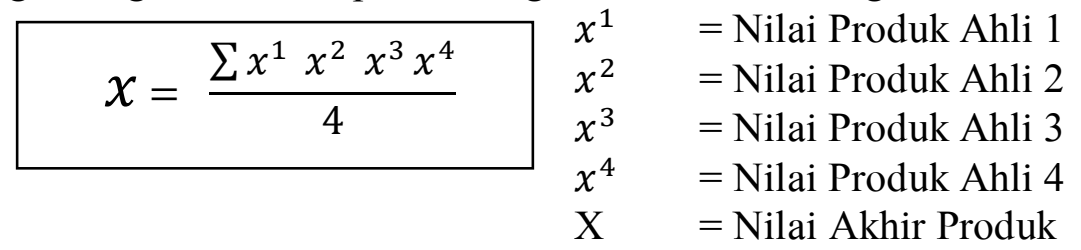

Untuk menafsirkan tingkat kelayakan produk, maka perlu dilakukan standardisasi kualitas produk sebagai berikut :

Tabel 1: Standardisasi Kualitas Produk

\begin{tabular}{|c|c|c|l|}
\hline No. & Nilai Rata - Rata & Kategori & \multicolumn{1}{|c|}{ Keterangan } \\
\hline 1. & $3.1-4.0$ & Sangat Baik & Layak digunakan dengan sedikit revisi \\
\hline 2. & $2.1-3.0$ & Baik & Layak digunakan dengan banyak revisi \\
\hline 3. & $1.1-2.0$ & Cukup & Layak digunakan dengan sangat banyak revisi \\
\hline 4. & $0.0-1.0$ & Kurang & Tidak layak digunakan \\
\hline
\end{tabular}

\section{Hasil Penelitian}

\section{a. Kondisi Pembelajaran Bahasa Arab di UIN Sumatera Utara}

Untuk mendapatkan data tentang kondisi pembelajaran bahasa Arab di Universitas Islam Negeri Sumatera Utara Medan, peneliti menggunakan metode observasi terhadap cara dosen mengajar bahasa Arab dalam mata kuliah bahasa Arab. Tujuan dari observasi ini adalah sebagai pijakan dalam melakukan pengembangan model pembelajaran bahasa Arab berbasis konstruktivisme. Instrumen pengumpul data yang digunakan adalah panduan observasi yang berisi tentang sejumlah poin pernyataan dengan dua alternatif pilihan; ya dan tidak. Jika hasil obsertvasinya "ya" berarti dosen tersebut telah melaksanakan pembelajaran berbasis konstruktivisme. Sebaliknya, jika hasil observasinya "tidak" berarti dosen dimaksud belum melaksanakan pembelajaran berbasis konstruktivisme, atau pembelajaran berbasis teori lain, seperti behaviorisme, kognitivisme, dll.

Berdasarkan prosentasi jawaban responden, dapat diketahui bahwa sebanyak 51,68 \% dosen bahasa Arab di UIN Sumatera Utara telah memakai pendekatan konstruktivisme, dan sisanya 48,32 \% masih mamakai pendekatan lain, termasuk pendekatan behaviorisme. Data ini juga menunjukkan bahwa telah ada potensi untuk pengembangan model pembelajaran bahasa Arab berbasis konstruktivisme.

\section{b. Pengembangan Model Pembelajaran Bahasa Arab Berbasis Konstruktivisme}

Pengembangan Model Pembelajaran Bahasa Arab Berbasis Konstruktivisme dilakukan sebagai berikut: (1) Studi kepustakaan, (2) Observasi pembelajaran bahasa Arab di UIN Sumatera Utara Medan, (3) Memilih dan menentukan jenis / desain pengembangan, (4) Mengembangkan model pembelajaran bahasa Arab berbasis konstruktivisme, (5) Validasi produk oleh para ahli, (6) Revisi, dan (7) Penyusunan laporan penelitian. Proses pengembangan dapat dijelaskan dalam bentuk bagan sebagai berikut: 


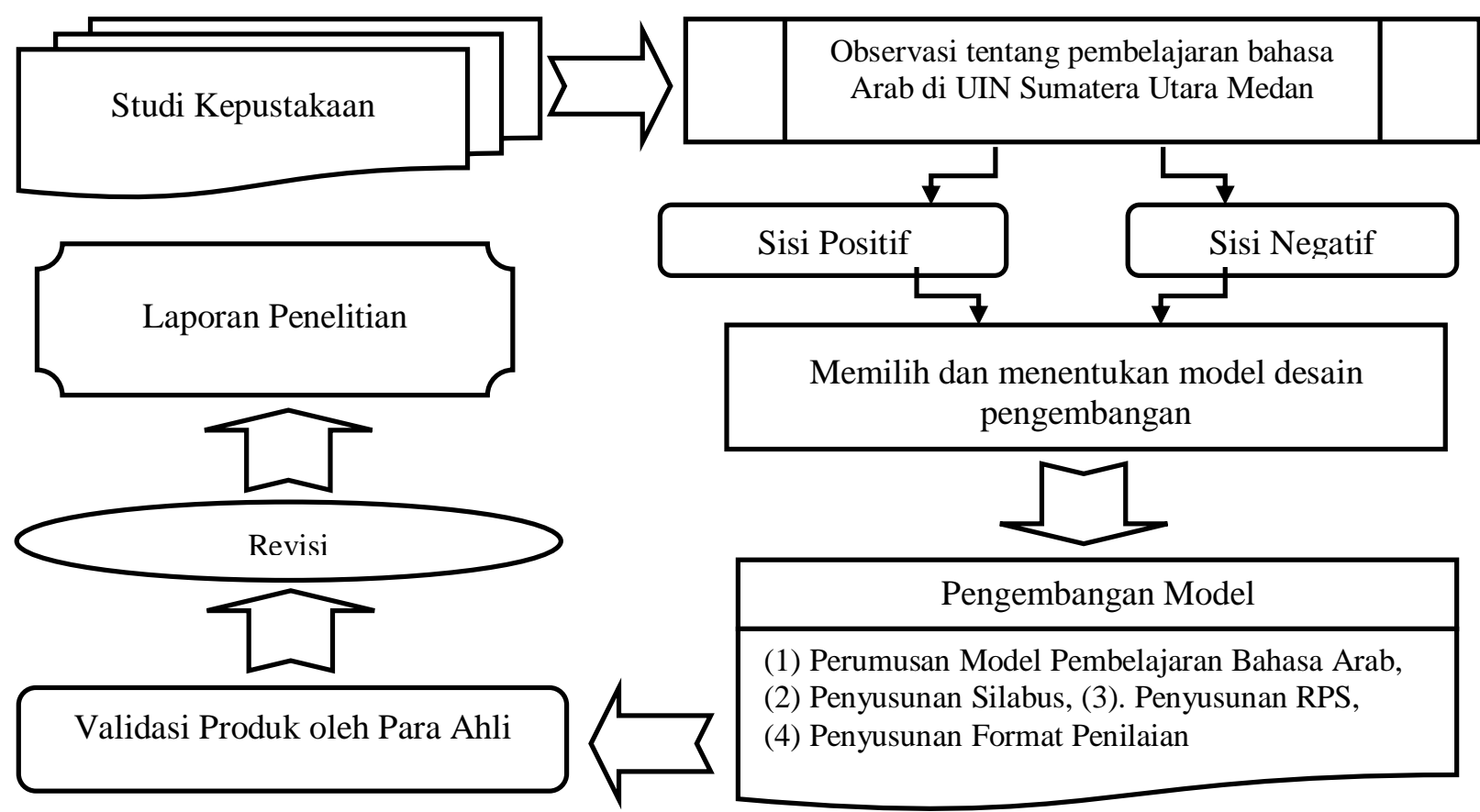

Gambar 4:

Proses Pengembangan Model

Alur proses pengembangan model pembelajaran bahasa Arab berbasis konstruktivisme di atas dapat dijelaskan sebagai berikut:

1. Studi kepustakaan tentang pembelajaran bahasa Arab dan ciri-ciri pembelajaran berbasis konstruktivisme. Pelacakan terhadap sejumlah referensi menyangkut pembelajaran bahasa Arab dan ciri - ciri pembelajaran berbasis konstruktivisme telah dilakukan sejak proposal ini disetujui di Lembaga Penelitian dan Pengabdian Masyarakat UIN Sumatera Utara Medan.

2. Melakukan observasi tentang pembelajaran bahasa Arab di UIN Sumatera Utara Medan. Berdasarkan hasil penelusuran terhadap sejumlah refensi, maka ditemukanlah teori-teori yang berkaitan dengan ciri-ciri pembelajaran bahasa Arab berbasis konstruktivisme. Karakteristik dimasuk dituangkan dalam pedoman observasi di kelas. Tujuan observasi untuk melihat secara nyata seberapa besar potensi yang dimiliki untuk pengembangan model pembelajaran bahasa Arab berbasis konstruktivisme. Hasil observasi dan deskripsinya sebagaimana terlihat di awal bab ini.

3. Memilih dan menentukan jenis/desain pengembangan. Langkah berikutnya dalam pengembangan ini adalah memilih dan menentukan desain pengembangan. Seperti yang telah dijelaskan dalam bab III bahwa desain pengembangan model yang dipakai adalah desain Four-D's dengan empat langkah: 1) Difine 2) Design 3) Development, dan 4) Dessemination. Setiap langkah tersebut juga terdapat beberapa tahapan.

4. Mengembangkan Model Pembelajaran Bahasa Arab Berbasis Konstruktivisme

a) Perumusan Model pembelajaran bahasa Arab

Perumusan Model pembelajaran bahasa Arab dimaksudkan untuk menjadi panduan dalam pembuatan Rencana Pembelajaran Semester (RPS). Rumusan dimaksud adalah : 
Arabi : Journal of Arabic Studies

Tabel 2: Rumusan Model Pembelajaran Bahasa Arab

\begin{tabular}{|c|c|c|c|c|c|c|c|}
\hline $\begin{array}{c}\text { Anâshir } \\
\text { Bahasa } \\
\text { Arab }\end{array}$ & \multicolumn{4}{|c|}{$\begin{array}{c}\text { Mahârah Bahasa } \\
\text { Arab }\end{array}$} & $\begin{array}{c}\text { Karakteristik } \\
\text { Pembalajaran } \\
\text { Kontruktivisme }\end{array}$ & $\begin{array}{l}\text { Altenatif Strategi } \\
\text { Pembelajaran }\end{array}$ & $\begin{array}{l}\text { Alternatif Metode } \\
\text { Pembelajaran }\end{array}$ \\
\hline Ashwät & \multirow[b]{2}{*}{ 永 } & \multirow[b]{2}{*}{ స్ } & \multirow[b]{2}{*}{ 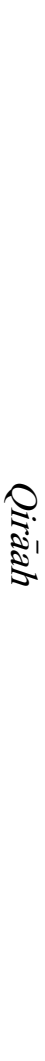 } & & \multirow[b]{2}{*}{$\begin{array}{ll}\text { 1. } & \text { Orientasi } \\
\text { 2. } & \text { Elicitasi } \\
\text { 3. } & \text { Restrukturisasi } \\
\text { ide } \\
\text { 4. Penggunaan ide } \\
\text { 5. } \\
\text { Review/Evaluasi }\end{array}$} & \multirow[b]{2}{*}{$\begin{array}{l}\text { - Cooperatif Learning, } \\
\text { - Contextual Teaching } \\
\text { and Learning, } \\
\text { - Inquiri Learning dan } \\
\text { - Problem Based } \\
\text { Learning }\end{array}$} & $\begin{array}{l}\text { Eclectik Methode dengan } \\
\text { alternatif: } \\
\text { - Brainstorming, } \\
\text { - Ice Breakingg, } \\
\text { - al-Tharíqah al-Ilqāiyah, } \\
\text { - al-Thariqah al- } \\
\text { - Hiwäriyah; } \\
\text { - al-Tharíqah al- }\end{array}$ \\
\hline Mufradāt & & & & \begin{tabular}{l}
$\pi$ \\
\multirow{2}{*}{} \\
\multirow{2}{*}{}
\end{tabular} & & & $\begin{array}{l}\text { Istiqraiyah/ } \\
\text { Istinbathiyah; } \\
\text { - Tharíqah al- } \\
\text { Mubāsyarah; } \\
\text { - Tharīqah al-Qirāah; } \\
\text { - al-Thariqah al- } \\
\text { Sam'iyah al- } \\
\text { Syafawiyah/al- } \\
\text { Bashariyah; } \\
\text { - Induktif; } \\
\text { - Simulasi; } \\
\text { - Bermain Peran; } \\
\text { - Demonstrasi; } \\
\text { - Al-Al'āb al- } \\
\text { Lughawiyah }\end{array}$ \\
\hline
\end{tabular}

b) Penyusunan Silabus Mata Kuliah Bahasa Arab

Silabus Mata Kuliah Bahasa Arab dikembangkan berdasarkan 'anāshir dan mahārah bahasa Arab. Pengembangan silabus mata kuliah bahasa Arab berbasis konstruktivisme memuat: identitas mata kuliah bahasa Arab, Capaian Pembelajarn (Sikap. Pengetahuan, Keterampilan Umum dan Keterampulan Khusus), Deskripsi Mata Kuliah, Topik-topik pembelajaran dan Referensi. Sebagai berikut:

Tabel 3: Pengembangan Silabus Mata Kuliah Bahasa Arab

\begin{tabular}{|c|c|c|}
\hline Mata Kuliah & & Bahasa Arab I \\
\hline Kode & & \\
\hline sks & : & 2 sks \\
\hline Program Studi & & Program Studi selain Kebahasaaraban \\
\hline Dosen Pengampu & & \\
\hline Capaian Pembelajaran & & \\
\hline Sikap (S) & & $\begin{array}{l}\text { 1. Menghargai keanekaragamanan budaya, pandangan, agama, dan } \\
\text { kepercayaan serta pendapat atau temuan orisinal orang lain. (Poin 5) } \\
\text { 2. Menunjukkan sikap bertanggung jawab atas pekerjaan di bidang } \\
\text { keahaliannya secara mandiri. (Poin 9) }\end{array}$ \\
\hline $\begin{array}{l}\text { Keterampilan Umum } \\
\text { (KU) }\end{array}$ & & $\begin{array}{l}\text { 1. Mampu menunjukkan kinerja mandiri, bermutu dan terukur. (Poin 2) } \\
\text { 2. Mampu mengambil keputusan secara tepat dalam konteks penyelesaian } \\
\text { masalah di bidang keahliannya berdasarkan hasil analisis informasi dan } \\
\text { data. (poin 5) }\end{array}$ \\
\hline Pengatahuan $(\mathrm{P})$ & & $\begin{array}{l}\text { 1. Mampu menganalisis semua anāshir bahasa Arab bahasa Arab (ashwāt, } \\
\text { mufradàt dan tarkīb). } \\
\text { 2. Mampu menganalisa semua mahārah bahasa Arab (istimāa, kalām, }\end{array}$ \\
\hline
\end{tabular}




\section{Arabi : Journal of Arabic Studies}

qirāah dan kitābah) pada semua anāshir bahasa Arab.

\section{Keterampilan}

Khusus

1. Mahasiswa mampu membandingkan persamaan dan perbedaan huruf huruf hijaiyah bahasa Arab dan abjadiyah bahasa Indonesia, baik secara lisan (pelafalan) maupun secara tertulis dengan benar. (KU.2).

2. Mahasiswa mampu mempraktikkan penggunaan sejumlah mufradāt, terkait dengan mudzakkar-muannats, isim dhamīr, isim istifhām, pada semua keterampilan bahasa Arab dengan benar. (KU.2).

3. Mahasiswa mampu mempraktikkan penggunaan tarkỉb dalam bentuk jumlah ismiyyah dan jumlah fi'liyyah pada semua keterampilan bahasa Arab dengan benar. (KU.2).

\section{Deskripsi Mata Kuliah}

Mata Kuliah bahasa Arab-I ini membelajarkan ketiga 'anāshir bahasa Arab (ashwāt, mufradāt dan tarākīb) dalam semua keterampilan berbahasa Arab (istimā', kalām, qirāah dan kitābah).

\begin{tabular}{|c|c|c|}
\hline \multicolumn{3}{|l|}{ Topik-Topik } \\
\hline 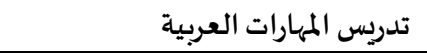 & تدريس العناصر العربية & \\
\hline & \multicolumn{2}{|c|}{ ا. تدريس الأهوات } \\
\hline الاستماع، والكلام، والقراءة والكتابة & مقارنة الحروف الهجائئة العربية والأبجدية الإندونيسية & - \\
\hline \multirow[t]{2}{*}{ الاستماع، والكلام، والقراءة والكتابة } & مخارج الحروف العربية & - \\
\hline & \multicolumn{2}{|c|}{ 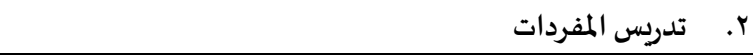 } \\
\hline الاستماع، والكلام، والقراءة والكتابة & التعارف (أنواع الكلمة العربية) & - \\
\hline الاستماع، والكلام، والقراءة والكتابة & الجامعة (اسم المذكر والمؤنث) & - \\
\hline الاستماع، والكلام، والقراءة والكتابة & الهواية (أسماء الإشارة) & - \\
\hline الاستماع، والكلام، والقراءة والكتابة & أعضياء الجسم (أسماء الاستفهام) & - \\
\hline الاستماع، والكلام، والقراءة والكتابة & السكن (أسماء الضمائر) & - \\
\hline الاستماع، والكلام، والقراءة والكتابة & السفر (الحروف الجر) & - \\
\hline \multirow[t]{2}{*}{ الاستماع، والكلام، والقراءة والكتابة } & السوق (أقسام الأفعال) & - \\
\hline & \multicolumn{2}{|c|}{ r. تدريس التراكيب } \\
\hline الاستماع، والكلام، والقراءة والكتابة & الأسرة (المبتدأ والخبر) & - \\
\hline الاستماع، والكلام، والقراءة والكتابة & الوسائل الاجتماعية (الخبر المقدم والمبتدأ المؤخر) & - \\
\hline الاستماع، والكلام، والقراءة والكتابة & الخبرات ( فعل المماضي والفاعل والمعفول به والجر والمجرور) & - \\
\hline الاستماع، والكلام، والقراءة والكتابة & المهنة (فعل المضارع والفاعل والمعفول باهوالجر والمجرور) & - \\
\hline الاستماع، والكلام، والقراءة والكتابة & الأنشطة اليومية (فعل ألأمر إلمعفول به والجر والمجرور) & - \\
\hline
\end{tabular}

\section{Referensi :}

$$
\begin{aligned}
& \text { - العربية للناشئين، وزارة المعارف - المملكة العربية السعودية. } \\
& \text { - } \\
& \text { - العبية بين يديك - سلسلة في تعليم اللغة العربية لغير الناطقين بها - المملكة العربية السعودية }
\end{aligned}
$$

Ciri konstruktivisme dalam silabus ini antara lain: kontekstual, situasional, aplikatif, induktif dan berorintasi kepada skil dan keterampilan berbahasa.

\section{c) Penyusunan Rencana Pembelajaran Semester (RPS) Mata Kuliah Bahasa Arab}

Pembuatan pembuatan Rencana Pembelajaran Semester (RPS) mata kuliah bahasa Arab I mengacu kepada permenristekdikti No. 44 Tahun 2015 tentang Standar Nasional Pendidikan Tinggi yang memuat: (a) Nama program studi, nama dan kode mata kuliah, semester, sks, nama dosen pengampu; (b) Capaian pembelajaran lulusan yang dibebankan pada mata kuliah, (c) Kemampuan akhir yang direncanakan pada tiap tahap pembelajaran untuk memenuhi capaian pembelajaran lulusan, (d) Bahan kajian yang terkait dengan kemampuan yang akan dicapai, (e) Metode pembelajaran, (f) Waktu yang disediakan untuk mencapai kemampuan pada tiap tahap 
pembelajaran, (g) Pengalaman belajar mahasiswa yang diwujudkan dalam deskripsi tugas yang harus dikerjakan oleh mahasiswa selama satu semester, (h) Kriteria, indikator, dan bobot penilaian; dan (i) Daftar referensi yang digunakan. Semua karakteristik Rencana Pembelajaran Semester (RPS) di atas dimasukkan dalam format RPS Mata Kuliah Bahasa Arab.

Karakteristik Rencana Pembelajaran Semester (RPS) Mata Kuliah Bahasa Arab yang dikembangkan adalah bahwa pada kolom metode pembelajaran dimuat altetnatif strategi dan metode pembelajaran berbasis konstruktivisme serta dalam kolom pengalaman belajar mahasiswa dimuat semua langkah-langkah pembelajaran konstruktivisme, sebagaimana dapat dilihat contohnya dalam lampiran I.

\section{d) Penyusunan Format Penilaian}

Jenis penilaian yang dikembangkan dalam pembelajaran bahasa Arab berbasis konstruktivisme adalah penilaian autentik. Penilaian autentik adalah bentuk penilaian untuk mengukur afektif, pengetahuan dan keterampulan siswa. Penilaian autentik bertujuan untuk mendeskripsikan berbagai bentuk penilaian yang dapat menggambarkan hasil belajar siswa, motivasi, pemerolehan belajar dan sikap-sikap terhadap kegiatan kelas yang relevan dengan pembelajaran.

Alternatif jenis penilaian autentik yang dikembangkan dalam pembelajaran bahasa Arab berbasis konstruktivisme adalah: (a). Penilaian Proses, yaitu salah satu jenis penilaian pembelajaran berpendekatan konstruktivisme. Pendekatan konstruktivisme tidak hanya berorintasi kepada hasil, tetapi juga proses, bahkan menurut pendekatan ini, proses lebih penting dari pada hasil. (b). Penilaian Portofolio, yaitu sebuah penilaian yang memusatkan pada koleksi karya siswa untuk menunjukkan kemajuannya sepanjang waktu. Beberapa keunggulan Penilaian Portofolio adalah sebagai berikut: (1) Memadukan informasi dari berbagai sumber, (2) Memberikan gambaran tentang kinerja dan belajar mahasiswa. (3) Keterlibatan dan komitmen mahasiswa yang kuat, (4). Menghimbau evaluasi diri bagi mahasiswa.

\section{c. Validasi Produk oleh Para Ahli}

Masing-masing validator diberi angket penilaian yang terdiri dari 13 butir pernyataan yang dimodifikasi dari Akbar (2017:77-78), dengan empat alternatif skor: $4=$ sangat baik, $3=$ baik, $2=$ sedang, 1 = kurang. Butir-Butir angket dimaksud dimodifikasi dari Sa'dun Akbar (2013: 77-78).

Hasil validasi kedua orang ahli di bidang pembelajaran konstruktivisme, sebagai berikut:

Tabel 4: Nilai Validasi Produk oleh Para Ahli Pembelajaran Konstruktivisme

\begin{tabular}{|c|l|c|c|}
\hline No & \multicolumn{1}{|c|}{\begin{tabular}{|c|}
\multicolumn{1}{|c|}{ Nilai } \\
\multicolumn{1}{|c|}{ Pernyataan }
\end{tabular}} & \multicolumn{1}{|c|}{ Validator } \\
\cline { 2 - 4 } & \multicolumn{1}{|c|}{ I } & II \\
\hline 1. & $\begin{array}{l}\text { Kesesuaian model pembelajaran yang dikembangkan dengan prinsip - prinsip } \\
\text { pembelajaran konstruktivisme. }\end{array}$ & 3 & 4 \\
\hline 2. & $\begin{array}{l}\text { Kesesuaian model pembelajaran dengan karakteristik pembelajaran di Perguruan } \\
\text { Tinggi. }\end{array}$ & 3 & 4 \\
\hline 3. & $\begin{array}{l}\text { Kesesuaian model pembelajaran yang dikembangkan dengan tingkat perkembangan } \\
\text { mahasiswa. }\end{array}$ & 3 & 3 \\
\hline 4. & $\begin{array}{l}\text { Perkiraan kemampuan model pembelajaran yang dikembangkan dalam menciptakan } \\
\text { komunikasi aktif antar mahasiswa dan antar mahasiswa dan dosen serta lingkungan } \\
\text { belajar di sekitarnya. }\end{array}$ & 2 & 3 \\
\hline 5. & $\begin{array}{l}\text { Perkiraan kemampuan model pembelajaran yang dikembangkan dalam mengarahkan } \\
\text { mahasiswa untuk melakukan eksplorasi pengetahuan. }\end{array}$ & 3 & 3 \\
\hline 6. & $\begin{array}{l}\text { Perkiraan kemampuan model pembelajaran yang dikembangkan dalam mengarahkan } \\
\text { mahasiswa untuk melakukan elaborasi. }\end{array}$ & 3 & 4 \\
\hline 7. & $\begin{array}{l}\text { Perkiraan kemampuan model pembelajaran yang dikembangkan dalam mengarahkan } \\
\text { mahaiswa untuk melakukan konfirmasi. }\end{array}$ & 3 & 3 \\
\hline 8. & $\begin{array}{l}\text { Kesesuaian RPS yang dikembangkan dengan tuntutan Standar Nasional Pendidikan } \\
\text { Tinggi (SNPT). }\end{array}$ & 4 & 3 \\
\hline 9. & Ketepatan langkah - langkah pembelajaran dalam model pembelajaran bahasa Arab & 2 & 3 \\
\hline
\end{tabular}




\section{Arabi : Journal of Arabic Studies}

\begin{tabular}{|c|l|c|c|}
\hline & yang dikembangkan. & & \\
\hline 10. & $\begin{array}{l}\text { Kemampuan model pembelajaran bahasa Arab yang dikembangkan dalam memberi } \\
\text { tugas secara individual dan/atau kelompok. }\end{array}$ & 2 & 4 \\
\hline 11. & $\begin{array}{l}\text { Cakupan instrumen penilaian untuk mengukur perkembangan kompetensi mahasiswa } \\
\text { dalam belajar bahasa Arab. }\end{array}$ & 3 & 4 \\
\hline 12. & Ketepatan instumen asesmen untuk evaluasi dan penilaian. & 4 & 3 \\
\hline 13. & $\begin{array}{l}\text { Penilaian secara umum terhadap model pembelajaran bahasa Arab yang } \\
\text { dikembangkan. }\end{array}$ & 3 \\
\hline
\end{tabular}

Hasil angket yang diberikan kepada dua orang ahli di bidang pembelajaran bahasa Arab, sebagai berikut:

Tabel 5: Nilai Validasi Produk oleh Para Ahli Pembelajaran Bahasa Arab

\begin{tabular}{|c|c|c|c|}
\hline \multirow[t]{2}{*}{ No } & \multirow[t]{2}{*}{ Pernyataan } & \multicolumn{2}{|c|}{$\begin{array}{c}\text { Nilai } \\
\text { Validator }\end{array}$} \\
\hline & & I & II \\
\hline 1. & Ketepatan perumusan tujuan pembelajaran bahasa Arab dalam RPS. & 4 & 4 \\
\hline 2. & $\begin{array}{l}\text { Penyusunan materi ajar bahasa Arab dalam silabus dan/atau RPS, telah } \\
\text { mempertimbangkan pengalaman dan pengetahuan yang dimiliki mahasiswa } \\
\text { sebelumnya. }\end{array}$ & 4 & 3 \\
\hline 3. & $\begin{array}{l}\text { Penyusunan materi ajar bahasa Arab (dalam silabus dan/atau RPS) telah memenuhi } \\
\text { 'anāshir bahasa Arab dengan lengkap. }\end{array}$ & 4 & 3 \\
\hline 4. & $\begin{array}{l}\text { Penyusunan materi ajar bahasa Arab (dalam silabus dan/atau RPS) telah memenuhi } \\
\text { aspek-aspek mahārah bahasa Arab dengan lengkap. }\end{array}$ & 4 & 4 \\
\hline 5. & $\begin{array}{l}\begin{array}{l}\text { Penyusunan materi ajar bahasa Arab (dalam silabus } \\
\text { mencerminkan prinsip tadarruj (gradasi). }\end{array} \\
\end{array}$ & 4 & 4 \\
\hline 6. & $\begin{array}{l}\text { Kesesuaian materi ajar bahasa Arab yang dikembangkan (dalam silabus dan/atau RPS) } \\
\text { dengan heterogenitas mahasiswa (latar belakang pendidikan, program studi, dan } \\
\text { motivasi belajar bahasa Arab). }\end{array}$ & 4 & 3 \\
\hline 7. & $\begin{array}{l}\text { Pemilihan tarākīb yang aplikatif (sesuai silabus dan/atau RPS) dalam pembelajaran } \\
\text { bahasa Arab yang dikengembangkan. }\end{array}$ & 4 & 4 \\
\hline 8. & $\begin{array}{l}\text { Topik-topik pembelajaran bahasa Arab dalam silabus dan/atau RPS dipilih } \\
\text { berdasarkan keseringan penggunaannya dalam lingkungan dan keseharian peserda } \\
\text { didik. }\end{array}$ & 4 & 4 \\
\hline 9. & $\begin{array}{l}\text { Ketepatan pemilihan pendekatan, strategi dan metode pembelajaran bahasa Arab } \\
\text { dalam mewujudkan proses pembelajaran yang aktif dan bermakna, seseuai dengan } \\
\text { konsep konstruktivisme. }\end{array}$ & 4 & 4 \\
\hline 10. & $\begin{array}{l}\text { Ketepatan pemilihan jenis evaluasi pembelajaran bahasa Arab dalam mendorong } \\
\text { mahasiswa untuk membangun pengetahuannya secara mandiri. }\end{array}$ & 3 & 3 \\
\hline 11. & $\begin{array}{l}\text { Ketepatan instrumen assessmen untuk evaluasi dan penilaian pembelajaran bahasa } \\
\text { Arab. }\end{array}$ & 3 & 3 \\
\hline 12. & $\begin{array}{l}\text { Perkiraan kemampuan model pembelajaran bahasa Arab yang dikembangkan dalam } \\
\text { mengembangkan kompetensi dan performa mahasiswa dalam bahasa Arab. }\end{array}$ & 4 & 4 \\
\hline 13. & $\begin{array}{lllllll}\begin{array}{l}\text { Penilaian secara } \\
\text { dikembangkan }\end{array} & \text { umum terhadap model pembelajaran bahasa Arab yang } \\
\end{array}$ & 3 & 4 \\
\hline & Total & 49 & 47 \\
\hline
\end{tabular}

Analisis validasi para ahli terhadap produk model pembelajaran bahasa Arab yang dikembangkan adalah sebagai berikut: (1) Hasil rata-rata nilai yang diberikan oleh ahli pembelajaran konstruktivisme-1 sebesar 2,9. Dengan demikian, produk pengembangan model pembelajaran bahasa Arab berbasis konstruktivisme adalah baik. (2) Hasil rata-rata nilai yang diberikan oleh ahli pembelajaran konstruktivisme-2 sebesar 3,3. Dengan demikian, produk 
pengembangan model pembelajaran bahasa Arab berbasis konstruktivisme adalah sangat baik. (3) Hasil rata-rata nilai yang diberikan oleh ahli Ahli Bahasa Arab-1 sebesar 3,6. Dengan demikian, produk pengembangan model pembelajaran bahasa Arab berbasis konstruktivisme adalah sangat baik. (4) Hasil rata-rata nilai yang diberikan oleh ahli Ahli Bahasa Arab-2 sebesar 3,7. Dengan demikian, produk pengembangan model pembelajaran bahasa Arab berbasis konstruktivisme adalah sangat baik.

Nilai rata - rata keempat ahli di atas dijumlahkan untuk memperoleh nilai akhir tentang kualitas model pembelajaran bahasa Arab berbasis konstruktivisme sebagai berikut:

$$
x=\frac{\sum x^{2.9} x^{3.3} x^{3.6} x^{3.7}}{4} \quad x=3.37
$$

Berdasarkan tabel 3.1 diketahui bahwa nilai 3.37 menunjukkan bahwa menurut para ahli produk pengembangan model pembelajaran bahasa Arab berbasis konstruktivisme adalah sangat baik.

\section{d. Revisi Produk}

Berdasarkan masukan dan komentar para ahli, produk model pembelajaran bahasa Arab yang dikembangkan berbasis konstruktivisme telah direvisi atau disempurnakan.

Sesuai masukan dan komentar para ahli, produk model pembelajaran bahasa Arab yang dikembangkan berbasis konstruktivisme direvisi atau disempurnakan. Berikut revisi produk berdasarkan masukan dan komentar para ahli.

1) Ahli Pembelajaran Konstruktivisme-1 memberikan masukan atau komentar sebagai berikut: Tabel 6: Masukan dari Ahli Pembelajaran Konstruktivisme-1

\begin{tabular}{|c|c|}
\hline Masukan & Perbaikan \\
\hline $\begin{array}{l}\text { 1. Untuk capaian mata kuliah, sebaiknya dirinci ke } \\
\text { dalam ranah kogitif, afektif, dan psikomotorik } \\
\text { denga nmempertimbangkan capaian kompetensi } \\
\text { bahasa menyimak, berbicara, membaca dan } \\
\text { menulis). }\end{array}$ & $\begin{array}{l}\text { Capaian pembelajaran direvisi menjadi: } \\
\text { Mahasiswa mampu menganalisis semua } \\
\text { unsur bahasa Arab ('ashwät, mufradāt dan } \\
\text { tarkīb) dan mengaplikasikannya pada semua } \\
\text { keterampilan berbahasa Arab (istimā', } \\
\text { kalām, qirāah, dan kitābah) dengan sikap } \\
\text { percaya diri, semagat, kerja sama dan } \\
\text { menghargai orang lain. } \\
\text { Sebelumnya hanya "Mahasiswa mampu } \\
\text { mempraktekkan semua unsur bahasa Arab } \\
\text { ('anāshir al-lughah) dalam semua } \\
\text { keterampilan berbahasa Arab (istimā', } \\
\text { kalām, qirāah, dan kitäbah)." }\end{array}$ \\
\hline $\begin{array}{l}\text { 2. Langkah model/strategi seharusnya } \\
\text { menyesuaikan dengan capaian kompetensi (tidak } \\
\text { harus sama semua) perlu variasi strategi, metode } \\
\text { dan penggunaan media sehingga pengalaman } \\
\text { mahasiswa bervariasi untuk capapan } \\
\text { kompetensi. }\end{array}$ & $\begin{array}{l}\text { Pengalaman belajar mahasiswa (sebagai } \\
\text { langkah-langkah strategi/model) telah } \\
\text { disesuaikan dengan capaian kompetensi } \\
\text { pembelajaran untuk setiap pertmuan. }\end{array}$ \\
\hline $\begin{array}{l}\text { 3. Kata "mempraktikkan" pada poin } 2 \text { capaian } \\
\text { pembelajaran aspek pengetahuan dalam silabus, } \\
\text { dirubah menjadi "menganalisa", sebab kata } \\
\text { "mempraktikkan" lebih tepat digunakan untuk } \\
\text { aspek keterampilan khusus. }\end{array}$ & $\begin{array}{l}\text { Mampu menganalisis semua mahārah bahasa } \\
\text { Arab (istimā', kalām, qirāah, dan kitābah) } \\
\text { pada semua 'anāshir bahasa Arab. }\end{array}$ \\
\hline $\begin{array}{l}\text { 4. Dalam RPS pada kolom kriteria dan indikator } \\
\text { penilaian, khususnya pada aspek keterlibatan } \\
\text { mahasiswa, perlu disesuaikan dengan capaian } \\
\text { sikap dalam silabus. }\end{array}$ & $\begin{array}{l}\text { Ditambah satu poin "Menghargai pendapat } \\
\text { orang lain" agar sesuai dengan capaian sikap } \\
\text { dalam silabus. }\end{array}$ \\
\hline $\begin{array}{l}\text { 5. Form penilaian proses (ranah afektif) harus } \\
\text { disesuaikan dengan capaian sikap. }\end{array}$ & $\begin{array}{l}\text { Aspek yang dinilai ditambah satu poin yaitu } \\
\text { "Toleransi" }\end{array}$ \\
\hline
\end{tabular}


6. Penulisan nama dicontoh penilaian hendaknya menggunakan inisial.

7. Form penilaian proses (ranah kognitif dan psikomotorik) harus direvisi, karena belum ada keterwakilan kognitif.
Nama yang ada di form penilaian telah direvisi menjadi inisial.

Aspek yang dinilai ditambah satu poin, yaitu "kesahihan konsep"”

2) Ahli Pembelajaran Konstruktivisme-2 memberikan masukan atau komentar sebagai berikut:

Tabel 7: Masukan dari Ahli Pembelajaran Konstruktivisme-2

\begin{tabular}{|ll|l|}
\hline \multicolumn{1}{|c|}{ Masukan } & \multicolumn{1}{|c|}{ Perbaikan } \\
\hline 1. & $\begin{array}{l}\text { Perbaiki cara penulisan yang salah: Startegi, } \\
\text { Cooveratif, Laerning, Ingkuiri, } \\
\text { keanekaramaman, mengambul, mempraktekkan } \\
\text { membelarakan, keahaliannya, restrukturiasi }\end{array}$ & $\begin{array}{l}\text { Direvisi menjadi: Strategi, Kooperatif, } \\
\text { Learning, dan Inkuiri, keanekaragaman, } \\
\text { mengambil, mempraktikkan, membelajarkan, } \\
\text { keahliannya, restrukturisasi. }\end{array}$ \\
\hline $\begin{array}{l}\text { 2. } \\
\text { Kata Inkuiri di kolom alternatif metode } \\
\text { hendaknya dibuang, sebab sudah ada di kolom } \\
\text { alternatif strategi pembelajaran }\end{array}$ & $\begin{array}{l}\text { Metode inquiri telah dihapus dari kolom } \\
\text { alternatif metode. }\end{array}$ \\
\hline 3. & $\begin{array}{l}\text { Pada bagian keterampilan khusus No. 1-3 } \\
\text { tertulis dengan "baik dan benar" seharusnya } \\
\text { dengan "benar" saja }\end{array}$ & Kata "baik" telah dihapus. \\
\hline
\end{tabular}

3) Ahli Pembelajaran Bahasa Arab-1, secara khusus tidak memberikan memberikan masukan atau kritikan, namun memberikan komentar sebagai berikut: "berdasarkan pengalaman yang diterapkan di Ma'hah al-Jami'ah UIN Sumatera Utara Medan dalam pembelajaran bahasa Arab dapat disinergikan bahwa dari sekian jenis pendekatan ataupun metode pembelajaran yang ditawarkan di level Perguruan Tinggi dimana mereka sudah memiliki pengalaman belajar yang cukup panjang. Dengan kondisi ini perlu kiranya menggunakan metode pembelajaran bahasa Arab dengan suatu pendekatan yang lebih relevan terutama dalam hal rasa nyaman dan familiar, artinya tidak adanya rasa tertekan dan terbebani, sehingga menimbulkan kreativitas dan kemandirian dalam belajar."

Keingian atau harapan ahli ini merupakan tujuan dari pengembangan model pembelajaran bahasa Arab berbasis konstruktivisme. Pendekatan konstruktivisme dalam pembelajaran membuat suasana pembelajaran menjadi aktif, semua peserta didik akan merasa bertanggung jawab untuk keberhasilan bersama. Hal ini sesuai dengan teori Duffy dan Cunningham, dalam Jonassen (2003) sebagaimana dikutip Pribadi (2011: 155-156) menjelaskan bahwa beberapa alasan rasional yang melatarbelakangi penggunaan pendekatan konstruktivisme dalam proses pembelajaran yaitu:

a) Semua pengetahuan dan hasil belajar merupakan proses konstruksi pribadi.

b) Pengetahuan merupakan konstruksi peristiwa yang dialami dari berbagai sudut pandang atau perspektif.

c) Proses belajar harus berlangsung dalam konteks yang relevan.

d) Belajar dapat terjadi melalui media pembelajaran.

e) Belajar merupakan dialog sosial yang bersifat inhern.

f) Siswa yang belajar memiliki ragam latar belakang yang multidimensial.

g) Memahami pengetahuan yang dipelajari merupakan pencapaian utama manusia.

4) Ahli Pembelajaran Bahasa Arab-2, memberikan masukan atau komentar sebagai berikut:

Tabel 8: Masukan dari Ahli Pembelajaran Bahasa Arab-2

\begin{tabular}{|c|c|}
\hline Masukan & Perbaikan \\
\hline $\begin{array}{l}\text { 1. Konsistensi penggunaan istilah antara } \\
\text { "RPS" atau SAP. }\end{array}$ & Istilah SAP telah dikoreksi dengan istilah RPS. \\
\hline $\begin{array}{l}\text { 2. Alternatif Strategi pembelajaran } \\
\text { "mufradât' ditambah dengan }\end{array}$ & $\begin{array}{l}\text { Penggunaan metode"bernyanyi" dimasukkan dalam } \\
\text { alternatif metode pembelajaran bahasa Arab }\end{array}$ \\
\hline
\end{tabular}




\begin{tabular}{|c|c|c|}
\hline & $\begin{array}{l}\text { menggunakan "lagu", karena sudah } \\
\text { terbukti di beberapa penelitian bahwa } \\
\text { penggunaan "lagu" efektif dalam } \\
\text { pembelajaran mufradât. }\end{array}$ & khususnya pada sebagian pembelajaran mufradât. \\
\hline \multirow[t]{8}{*}{3.} & \multirow{8}{*}{ 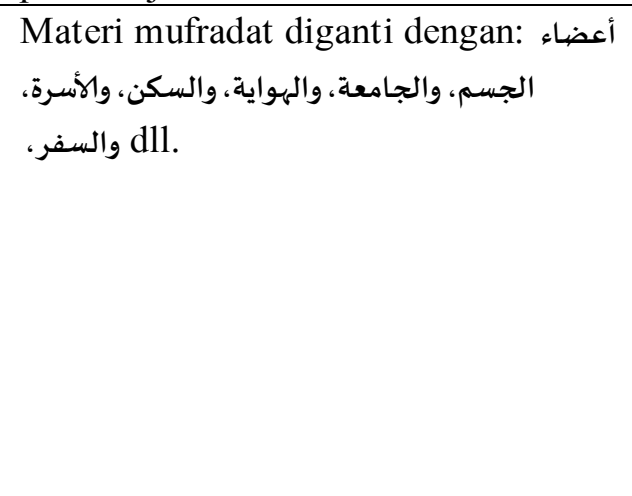 } & $\begin{array}{l}\text { Masukan ini peneliti akomodir, sehingga materi } \\
\text { silabus dan RPS direvisi sebagi berikut : }\end{array}$ \\
\hline & & - التعارف (أنواع الكلمة العببية) \\
\hline & & - الجامعة (اسم المذكر والمؤنث) \\
\hline & & - - الهواية (اسماء الإشارة) \\
\hline & & - أعضاء الجسم (أسماء الإستفهام) \\
\hline & & - السكن (اسماء الضمائر) \\
\hline & & - - السفر (الحروف الجر) \\
\hline & & - السوق (أقسام الأفعال) \\
\hline 4. & $\begin{array}{l}\text { Perlu diperbaiki kalimat berikut: } \\
\text { Mahasiswa mampu mempraktekkan } \\
\text { penggunaan sejumlah mufradāt } \\
\text { (mudzakkar-muannas, isim dhamir, } \\
\text { isim istifham) pada semua } \\
\text { keterampilan bahasa Arab dengan baik } \\
\text { dan benar. }\end{array}$ & $\begin{array}{l}\text { Kalimat dimaksud sudah diperbaiki menjadi: } \\
\text { Mahasiswa mampu mempraktekkan penggunaan } \\
\text { sejumlah mufradāt, terkait dengan mudzakkar- } \\
\text { muannas, isim dhamir, isim istifham, pada semua } \\
\text { keterampilan bahasa Arab dengan benar. }\end{array}$ \\
\hline
\end{tabular}

\section{Pembahasan Penelitian}

Berdasarkan temuan di atas, kondisi pembelajaran bahasa Arab di UIN Sumatera Utara Medan sudah mencapai $51 \%$ mengarah kepada penggunaan pendekatan konstruktivisme dalam pembelajaran bahasa Arab. Kondisi ini menjadi potensi besar untuk mengembangkan pembelajaran bahasa Arab berbasis konstruktivisme, karena sudah lebih dari $50 \%$ dosen-dosen bahasa Arab di UIN Sumatera Utara yang telah mempraktikkan proses pembelajaran bahasa Arab berbasis konstruktivisme. Di sisi lain, kondisi ini juga menjadi tantangan, sebab hampir $50 \%$ dosen-dosen bahasa Arab di UIN Sumatera Utara Medan harus mendapatkan informasi secara masif tentang pendekatan konstruktivisme dalam pembelajaran bahasa Arab, baik dari segi keunggulan dan kelemahannya. Tantangan ini akan semakin berat, mengingat dosen-dosen bahasa Arab di UIN Sumatera Utara Medan lebih dari $50 \%$ tidak linier dengan berlatar belakang pendidikannya. Kalaupun berlatar belakang pendidikan bahasa Arab, hanya strata satunya, sementara magister dan doktornya tidak jurusan pendidikan bahasa Arab.

Menurut pengamatan peneliti, dosen-dosen yang berlatang belakang pendidikan S.1 dan S2 nya pendidikan bahasa Arab, telah menerapkan pembelajaran aktif dalam proses pembelajaran bahasa Arab. Dengan demikian, kondisi ini berkaitan dengan linieritas keilmuan dosen bahasa Arab. Linieritas pendidikan tenaga pendidik dengan mata kuliah yang diampunya menjadi tuntutan undang-undang, sebagaimana diatur dalam pasal 10 ayat 2 Undang-Undang No. 12 tahun 2012 tentang Pendidikan Tinggi. Sebab, linieritas dimaksud menjadi indikator utama tentang komptensi dan kapabilitas seorang dosen dalam mengajarkan mata kuliah tertentu. Atau paling tidak mata kuliah dimaksud masih rumpun keilmuan dosen yang bersangkutan. Hal ini relevan dengan teori Pranowo (2014:44-45), bahwa di antara implikasi pendekatan konstruktivisme dalam pembelajaran bahasa -termasuk bahasa Arab untuk non Arab (peneliti)- adalah sebagai berkut (1) Guru bahasa harus menguasai bahasa yang diajarkannya secara baik dan memiliki pengetahuan dan pengalaman bagaimana mengajarkan bahasa tersebut, serta memiliki prinsip-prinsip umum linguistik. (2) Latihan pengucapan harus diberikan sejak awal dengan maksud untuk membentuk kebiasaan yang otomatis dalam mengucapkan bunyi-bunyi bahasa yang dipelajari secara benar tanpa ragu - ragu. (3) Cara melatih ucapan diawali dengan pemberikan deskripsi sederhana sebagaimana suatu bunyi bahasa dihasilkan dan diperbandingkan dengan bahasa pertama pembelajar. (4) Metode penyajian 


\section{Arabi : Journal of Arabic Studies}

semantik dalam arti penyajian digunakan metode langsung, maksudnya pemakaian bahasa ibu dihindarkan, diberikan dengan teks secara berulang-ulang dalam membaca, mendengarkan dan menulis. (5) Informasi gramatikal diberikan untuk mempermudah proses mempelajari bahasa. informasi mengenai tata bahasa bukan merupakan tujuan pengajaran. Oleh karena itu, pengajaran harus disampaikan secara induktif. (6) Teks bacaan yang diberikan harus berisi kehidupan dan kebudayaan penutur asli bahasa yang dipelajari dengan memperhatikan tingkat kesukaran bahasa dan isinya. (7) Interpretasi terhadap isi teks hendaknya dilakukan interpretasi secara pedagogik.

Berdasarkan teori di atas, hal tersebut disebut sebagai "tantangan" dalam penerapan teori konstruktivisme dalam pembelajaran bahasa Arab. Sebab banyak di antara dosen bahasa Arab di UIN Sumatera Utara Medan yang belum menguasai bahasa Arab secara baik dan seimbang. Dikatakan secara baik, artinya dosen bahasa Arab menguasai aspek 'anāshir bahasa Arab (ashwät, mufradāt, dan tarkīb). Sementara disebut seimbang dosen bahasa Arab diharapkan memiliki keterampilan yang saimbang dari semua mahărah bahasa Arab (Istimä', Kalām, Qirāah, dan Kitābah).

Ke depan dosen bahasa Arab di UIN Sumatera Utara Medan, diharapkan mampu: (1) Menguasai bahasa Arab secara baik dan seimbang, baik lisan maupun tulisan, (2) Menerapkan metode langsung, maksudnya mampu menggunakan bahasa Arab dan menghindari pemakaian bahasa ibu. (3) Melaksanakan pembelajaran secara induktif. (4) Memoles pembelajaran bahasa Arab yang relevan dengan budaya mahasiswa tanpa mengenyampingkan budaya Arab sebagai pemilik bahasa. (5) Mengnterpretasi materi pelajaran bahasa Arab secara pedagogik. (6) Model pembelajaran bahasa Arab berbasis konstruktivisme.

Model pembelajaran bahasa Arab berbasis konstruktivisme berhasil dikembangkan sesuai dengan langkah-langkah pengembangan model pembelajaran. Setiap penelitian dan pengembangan harus menggunakan model pengembangan tertentu atau memodifikasi satu model atau gabungan dari dua model. Penelitian ini menggunakan model pengembangan Four D's, sebuah model pengembangan yang direkomendasikan penemunya jika ingin produk penelitiannya dalam bentuk perangkat pembelajaran. Pemilihan model pengembangan Four D's dalam penelitian ini dianggap tepat, sebab produk penelitian ini adalah perangkat pembelaran.

Model pembelajaran bahasa Arab yang dikembangkan berbasis konstruktivisme diwujudkan dalam perangkat pembelajaran bahasa Arab, yang dalam hal ini mencakup: Silabus, Rencana Pembelajaran Semester dan Penilaian. Karena pada dasarnya, model itu abstrak atau hanya berupa teori. Untuk mengkongkritkannya, dituangkan dalam bentuk perangkat pembelajaran.

Disetiap perangkat pembelajaran dimaksud telah tertuang prinsip-prinsip pembelajaran konstruktivisme. Silabus bahasa Arab disusun secara kontekstual dan transdisipliner. Disebut kontekstual, karena topik-topik bahasannya dipilih hal-hal yang terkait langsung dengan kehidupan mahasiswa secara ril. Misalnya: perkenalan, aktivitas di kampus, hobbi, tempat tinggal, pasar, keluarga, dll. Disebut transdisipliner karena perangkat pembelajaran yang dikembangkan mendorong mahasiswa untuk menguasai ilmu-ilmu lain sebagai take and give bagi mata kuliah bahasa Arab.

Berdasarkan silabus tersebut, disusunlah Rencana Pembalajaran Semester (RPS) yang tercermin di dalamnya prinsip-prinsip konstruktivisme. Misalnya dipilih strategi-strategi dan metode-metode pembelajaran berbasis konstruktivisme. Juga diuraikan pengalaman belajar mahasiswa yang konstruktivis, seperi cara kerja dan berpikir induktif, kolaboratif, aktif, dll.

Strategi dan metode pembelajaran yang dipilih dalam RPS ini berbeda jauh dengan strategi dan metode pembelajaran yang dipilih dan diterapkan oleh sebagian dosen bahasa Arab di UIN Sumatera Utara Medan, yaitu metode ceramah, metode qāwa'id wa al-tarjamah (gramatikal), dan metode qiyāsi (deduktif). Metode-metode ini mencerminkan proses pembelajaran bahasa Arab bersifat teacher centre. Penggunaan metode-metode tersebut juga menunjukkan proses pembelajaran "tentang bahasa Arab" dan bukan pembelajaran "bahasa Arab". Pembelajaran 
"tentang bahasa Arab" berkonotasi penguasaan yang parsial terhadap bahasa Arab, sebab lebih mengutamakan penguasaan gramatikal daripada 'anāshir dan mahărah bahasa Arab.

Secara umum, strategi pembelajaran berbasis konstruktivisme yang tercermin dalam perangkat pembelajaran ini adalah strategi tidak langsung (Indirect Instruction); sebuah strategi diamana guru berperan sebagai fasilitator dalam proses pembelajaran. Penyampaikan materi seakan tidak langsung diberikan kepada mahasiswa, tapi melalui berbagai cara, media dan sumber belajar sehingga akhirnya materi dapat dipahami dengan baik oleh mahasiswa.

Pemilihan strategi pembelajaran tidak lansung sangat tepat dipraktekkan di perguruan tinggi, sebab strategi ini relevan dengan tingkat perkembangan mahasiswa, baik secara fisik, kognitif, dan afektif. Sebagimana disebutkan oleh Sani (2013:149), bahwa strategi pembelajaran tidak lansung sangat tepat dilakukan jika menginginkan hal-hal berikut: (1) Hasil belajar yang diharapkan berupa kemampuan berfikir tingkat tinggi. (2) Sikap, nilai, dan kemampuan interpersonal diharapkan dimiliki oleh perserta didik; (3) Proses belajar dinilai sama penting dengan produk belajar; (4) Peserta didik perlu menyelidiki atau menemukan sesuatu untuk mempelajari materi selanjutnya, (5) Dibutuhkan beberapa jawaban untuk suatu permasalahan, (6) Fokus pada pemahaman personal dan dan memori jangka panjang, (7) Keterlibatan individu dan motivasi instrinsik diharapkan muncul, (8) Dibutuhkan pengambilan keputusan dalam menyelesaikan permasalahan, (9) Kemampuan belajar sepanjang hayat perlu dikembangkan (Thobroni, 2011).

Penilaian pembelajaran bahasa Arab juga dipilih penilaian proses dan portofolio. Kedua jenis penilaian ini merupakan bagian dari beberapa penilaian berbasis konstruktivisme. Dipilihnya penilaian proses karena teori konstruktivisme tidak hanya berfokus kepada hasil, tetapi juga proses, bahkan proses lebih penting dari pada hasil. Menurut teori ini, jika prosesnya benar, maka hasilnyapun akan maksimal, sebaliknya jika prosesnya salah, maka hasilnyapun akan minimal. Sementara penilaian portofolio menggambarkan perkembangan afektif, kognitif, dan psikomotorik mahasiswa.

Rata-rata hasil penilaian/validasi para ahli terhadap produk model pembelajaran bahasa Arab yang dikembangkan berbasis konstruktivisme mencapai 3.37 (sangat baik). Grade ini tidak terlepas dari kesesuaian model yang dikembangkan dengan teori konstruktivisme dan peraturan pemerintah.

Dalam tabel model pembelajaran bahasa Arab telah tertuang strageti-strategi dan metodemetode pembelajaran berbasis konstruktivisme. Strategi dimaksud adalah: Cooperatif Learning, Contextual Teaching and Learning, Inquiri Learning dan Problem Based Learning. Hal ini sesuai dengan teori Wardoyo (2013: 44), bahwa diantara strategi pembelajaran yang tergabung dalam pendekatan konstruktivisme adalah Cooveratif Learning, Contextual Teaching and Laearning, Inquiry Learning dan Problem Based Learning. Dengan demikian, sangat wajar jika para ahli menilai bahwa model pembelajaran bahasa Arab ini telah memenuhi karakteristik pembelajaran konstruktivisme.

Pembuatan pembuatan Rencana Pembelajaran Semester (RPS) mata kuliah bahasa Arab mengacu kepada permenristekdikti No. 44 Tahun 2015 tentang Standar Nasional Pendidikan Tinggi. Dalam Rencana Pembelajaran Semester juga telah tertuang prinsip-prinsip pembelajaran berbasis konstruktivisme. Pengalaman belajar dimaksud adalah: (1) Mahasiswa membangun motivasinya sendiri agar semangat mengikuti pembelajaran bahasa Arab (istimā', kalām, qirāah, atau kitābah) (orientasi); (2) Mengaitkan informasi baru dengan pengetahuan yang sudah ada untuk membangun pengetahuan baru melalui diskusi (restrukturisasi); (3) Membuat dan/atau mengajukan pertanyaan terkait materi yang dipelajari (elicitasi); (4) Menerapkan (simulasi) materi sesuai dengan kebutuhan riil (penggunaan ide): (5) Melakukan feedback (review). (6) Membuat resume (induktif). (7) Menceritakan kegiatannya sehari-hari secara lisan maupun tulisan dengan menggunakan materi yang telah dipelajari (kontekstua), (8) Mengunduh video ttg matari yang dipelajari (mandiri); Pengalaman belajar di atas sesuai dengan teori pembelajaran Driver dan Oldman dalam Matthews, sebagaimana dikutip Suparno (2007:69-70). 


\section{Simpulan}

Kondisi pembelajaran bahasa Arab di UIN Sumatera Utara Medan masih sangat perlu diperbaiki dan ditingkatkan, sebab terdapat 48,32 \% dosen bahasa Arab masih mamakai pendekatan pembelajaran yang belum mendorong mahasiswa untuk belajar aktif, kolaboratif, dan percaya diri. Proses pembelajaran yang digunakan masih bersifat teacher center. Di sisi lain, terdapat 51,68 \% dosen bahasa Arab di UIN Sumatera Utara telah menggunakan pendekatan pembelajaran berbasis konstruktivisme. Proses pembelajaran sudah bersifat student center. Kondisi ini sangat potensial untuk melakukan pengembangan model pembelajaran bahasa Arab berbasis konstruktivisme di UIN Sumatera Utara Medan.

Jenis pengembangan desain model yang dipakai dalam penelitian ini adalah model Four D's, yang terdiri dari empat langkah: define, desain, development dan dessimination. Produk (Model Pembelajaran Bahasa Arab) yang dihasilkan melalui proses pengembangan ini adalah perangkat pembelajaran bahasa Arab yang mencakup: silabus bahasa Arab, RPS bahasa Arab, dan penilaian bahasa Arab.

Rata-rata nilai dari ahli pembelajaran konstruktivisme-1 adalah 2,9 (baik). Rata-rata nilai dari ahli pembelajaran konstruktivisme-2 adalah 3,3 (sangat baik). Rata-rata nilai dari ahli pembelajaran bahasa Arab-1 adalah 3,6 (sangat baik), Rata-rata nilai dari ahli pembelajaran bahasa Arab-2 adalah 3,6 (sangat baik). Jumlah nlai rata-rata dari keempat ahl adalah 3.37. Dengan demikian diketahui bahwa nilai 3.37 menunjukkan bahwa menurut para ahli produk pengembangan model pembelajaran bahasa Arab berbasis konstruktivisme adalah sangat baik.

Kepada seluruh dosen bahasa Arab di Perguruan Tinggi, khususnya di UIN Sumatera Utara Medan, disarankan untuk menerapkan atau menggunakan pendekatan konstruktivisme dalam pembelajaran bahasa Arab, sebab pendekatan konstruktivisme dalam pembelajaran relevan dengan tingkat usia dan pengalaman mahasiswa. Kepada pimpinan Perguruan Tinggi, khususnya di UIN Sumatera Utara Medan, diharapkan dapat mendorong melalui kebijakan kongkrit untuk penerapan atau penggunaan pendekatan konstruktivisme dalam pembelajaran bahasa Arab. Sebab tanpa melalui kebijakan pimpinan Perguruan Tinggi, penerapan pendekatan ini tidak bisa terlaksana secara komprehensif.[]

\section{Daftar Rujukan}

Abdullah, Umar al-Shadiq. 2008. Ta'Tim al-Lughah al-'Arabiyah li al-Näthiqīna bi ghairihā. Beirut: al-Dar al-'Alamiy.

Akbar, Sa'dun. 2013. Instrumen Perangkat Pembelajaran. Bandung: PT. Remaja Rosdakarya, Cet. $\mathrm{Ke}-2$.

Albantani, Azkia Muharom. 2018. Pembelajaran Bahasa Arab di UIN Syarif Hidayatullah Jakarta Teori dan Praktik. Tangerang Selatan: Cinta Buku Media.

Asrori, Imam. M. Thohir, dan M. Ainin. 2014. Evaluasi dalam Pembelajaran Bahasa Arab. Malang: Misykat, Cet ke-4.

Departemen Pendidikan dan Kebudayaan. 1995. Kamus Besar Bahasa Indonesia. Jakarta: Balai Pustaka.

al-Dhawiy, Munif Khudhair. 2013. Al-Nazhariyah al-Bināiyah wa Tathbīqātuhā fí Tadris alLughah al-Arabiyah, Istirātijiyāt Tadrìs al-Haditsah Namāzij li Taqwïm al-Bināiy. Riyadh: Fihras Maktabah al-Mulk.

Fachrurrazi, Aziz. dan Erta Mahyudin. 2016. Pembelajaran Bahasa Asing Tradisional \& Kontemporer. Jakarta: RajaGrafindo Persada. 
al-Fauzan, Abd al-Rahman bin Ibrahim. 2011. Idhāat li al-Mu'allimī al-Lughah al-'Arabiyah li ghair al-Näthiqīn bihă. Riyadh: Maktabah Malik Fahd.

Hizbullah, Nur. dan Zaqiatul Mardiah. 2014. "Masalah Pengajaran Bahasa Arab di Madrasah Aliyah di Jakarta", Jurnal Al-Azhar Indonesia Seri Humaniora, Vol. 2, No. 3.

Madkur, Ahli Ahmad. 2010. Thuruq Tadris al-Lughah al-'Arabiyah. 'Amman: Dār al-Masirah, Cet. $\mathrm{Ke}-2$.

Nasution, Sahkholid. 2016. “Tathwîr Namūzaj Tadrîs al-Nahwi fî Dhaw’i Nazhriyah Al-Ta'allum al-Binâiyah”, Disertasi, UIN Malang.

Nurohman, Sabar. 2008. "Peningkatan Thinking Skills Melalui Pembelajaran IPA Berbasis Kosntruktivisme di Sekolah Alam”, Jurnal Penelitian dan Evaluasi Pendidikan, Vol XI, No. 1 .

Pranowo. 2014. Teori Belajar Bahasa Untuk Guru Bahasa dan Mahasiswa Jurusan Bahasa. Yogyakarta: Pustaka Pelajar, Cet. 1.

Pribadi, Benny A. 2011. Model Desain Sistem Pembelajaran. Jakarta: PT. Dian Rakyat, Cet. 3.

al-Qursy, Jamal bin Ibrahim. 2009. Tharäiq al-Tadrīs. Riyadh: Maktabah al-Taubah, Cet. I.

Rusman. 2012. Model-Model Pembelajaran, Mengembangkan Profesionalisme Guru. Jakarta: PT. Raja Grafindo Persada, Cet. 5.

Sani, Ridwan Abdullah. 2013. Inovasi Pembelajaran. Jakarta: Bumi Aksara, Cet. 1.

Sanjaya, Wina. 2007. Strategi Pembelajaran Berorientasi Standar Proses. Jakarta: Kencana Prenada Media Group, Cet. III.

Schunk, Dale H. 2012. Learnig, Theories an Education Perspektive. Penerjemah: Eva Hamdiah dan Rahmat Fajar. Jakarta: Pustaka Pelajar, Cet. 1.

al-Shumaily, Yusuf. 1998. Al-Lughah al-'Arabiyah wa Thuruq Tadrīsihā Nazhariyah wa Tathbiqiyah. Beirut: al-Maktabah al-'Ashriyah.

Suparno, Paul. 2007. Filsafat Konstruktifisme dalam Pendidikan. Yogyakarya: Kanisius, Cet. 7.

Syafi'i, Isof. 2012. "Model Pembelajaran Bahasa Arab Berbasis Konstruktivisme di Perguruan Tinggi Islam", Jurnal Pendidikan Islam, Vol. 27, No. 3.

Thobroni, Muhammad. dan Arif Mustofa. 2011. Belajar dan Pembelajaran, Pengembangan Wacana dan Praktek Pembelajaran dalam Pembangunan Nasional. Yogyakarta: Ar-Ruzz Media, Cet. I.

Thu'aimah, Rusydi Ahmad. dkk. 2010. Al-Marji' fi Manāhij Ta'Tim al-Lughah al-'Arabiyah li alNäthiqīn bi Lughatin Ukhra. Kairo: Dār al-Fikr al-'Araby.

Tim Penyusun. 1999. Kamus Besar Bahasa Indonesia. Jakarta: Balai Pustaka.

Tim Penyusun. 2016. Statuta UIN Sumatera Utara Medan Tahun 2016. Medan: UIN Sumatera Utara.

Tiranto. 2013. Mendesain Model Pembelajaran Inovatif-Progresif, Konsep, Landasan, dan Implementasinya pada Kurikulum Tingkat Satuan Pendidikan (KTSP). Jakarta: Kencana Prenada Media Group, Cet. 6.

Trianto. 2011. Model-Model Pembelajaran Inovatif Berorietasi Konstruktifistik, Konsep Landasan Teoritis Praktis dan Implementasinya. Jakarta: Prestasi Pustaka, Cet. 5. 
Arabi : Journal of Arabic Studies

al-Ushaily, Abdul Aziz bin Ibrahim. 2002. Tharāiq Tadrīs al-Lughah al- 'Arabiyah li al-Näthiqīin bi Lughāt Ukhrā. Riyadh: Universitas Islam Imam Muhammad Bin Sa'ud.

Wardoyo, Sigit Mangun. 2013. Pembelajaran Konstruktivisme, Teori dan Aplikasi Pembelajaran Dalam Pembentukan Karakter. Bandung: Alfabeta, Cet. 1.

Yamin, Martinis. 2013. Strategi dan Metode dalam Model Pembelajaran. Jakarta: Referensi. 